\title{
Botany of two Antarctic mountain ranges: Gjelsvikfjella and Mühlig-Hofmannfjella, Dronning Maud Land
}

\author{
I. General ecology and development of the Antarctic cold desert cryptogam \\ formation
}

TORSTEIN ENGELSKJøN

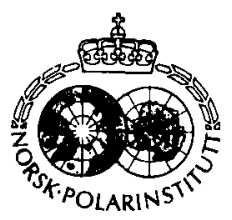

\begin{abstract}
Engelskjøn, T. 1986: Botany of two Antarctic mountain ranges: Gjelsvikfjella and Mühlig-Hofmannfjella, Dronning Maud Land. I. General ecology and development of the Antarctic cold desert cryptogam formation. Polar Research 4 n.s., 205-224.

The investigated area is located between $71^{\circ} 45^{\prime}$ and $72^{\circ} 20^{\prime} \mathrm{S}$ and between $1^{\circ} 35^{\prime}$ and $5^{\circ} 33^{\prime} \mathrm{E}$, from 1,080 to $2,695 \mathrm{~m}$ above sea level. An outline of climate, soil chemistry and main units of vegetation is provided. Of particular importance is the wet oasis area of Jutulsessen in Gjelsvikfjella which supports cyanophyceans, green algae, lichens and the mosses Grimmia lawiana and Sarconeurum glaciale, which have developed a series of distinctive communities. The nunataks fringing the Polar plateau harbour an impoverished cyanophycean and lichen vegetation up to approximately $2,500 \mathrm{~m}$ a.s.l., which is the highest elevation that macroscopic plant life has hitherto been reported in Antarctica. The thermal relations of the vegetation are discussed, based on the climatological record and on local measurements during the Norwegian Antarctic Research Expedition 1984/85. Some zonal and vertical belt subdivisions are indicated for this part of Greater Antarctica.
\end{abstract}

Torstein Engelskjøn, Botanical Garden and Museum, University of Oslo, Trondheimsveien 23 b, 0560 Oslo 5. Norway. December 1985 (revised May 1986).

The neighbouring mountain groups of Gjelsvikfjella and Mühlig-Hofmannfjella, Greater Antarctica (Fig. 1) were discovered from the air by the Schwabenland expedition in 1939 . Situated far from the coast, they remained unexplored until the British-Norwegian-Swedish Antarctic Research Expedition 1949-1952 (Roer 1954). Air photography for map construction was continued by the Norwegian Polar Research Institute, and map sheets of scale $1: 250,000$ covering the area treated here were edited in 1961-1966.

Extensive physiographic and geological investigations were carried out by the Fifth and Sixth Soviet Antarctic Expeditions 1959-1961 (Ravich \& Soloviev 1966), and ornithological observations from the same area published by Konovalov (1964) and Konovalov \& Shulyatin (1964).

However, there were few records of plant life in the Gjelsvikfjella and Mühlig-Hofmannfjella Mountains prior to the Norwegian Antarctic Research Expedition 1984/85. Only a few records are quoted (see Golubkova (1969) and SavichLjubitskaya \& Smirnova (1969)).

I joined the land party of Camp Norway 5 (Orheim 1985) working from the eastern outlier of the H. U. Sverdrupfjella Mountains at $1^{1} 35^{\prime} \mathrm{E}$, through Gjelsvikfjella, and to the western parts of Mühlig-Hofmannfjella as far east as $5^{\circ} 33^{\prime} \mathrm{E}$. The study area extends latitudinally from $71^{\circ} 45^{\prime}$ to $72^{\circ} 20^{\prime}$ S. Preliminary reports on biology and geology were published by Bech, Haftorn \& Mehlum (1985); Engelskjøn (1985); Sømuie (1985); Ohta \& Tørudbakken (1985).

\section{Previous botanical investigations in Dronning Maud Land}

Aspects of the terrestrial flora have been described from the Tottanfjella and Heimefrontfjella Mountains (Ardus 1964; Bowra, Holdgate \& Tilbrook 1966; Lindsay 1971), the Vestfjella Mountains (Lindsay 1972; Øvstedal 1983b), the H. U. Sverdrupfjella Mountains (Øvstedal 1983a), the Novolazarevskaya Station area including the Schirmacher oasis (Komárek \& Růžička 1966), the Syowa Station area (Akiyama 1967; Horikawa \& Ando 1967; Matsuda 1968; Kashiwadani 1970; Nakanishi 1977; Shimizu 1977; Yamanaka \& Sato 1977; Ando 1979), the Molodezhnaya Station area (MacNamara 1969, 1973), and the Sør-Rondane Mountains (Dodge 1962). 


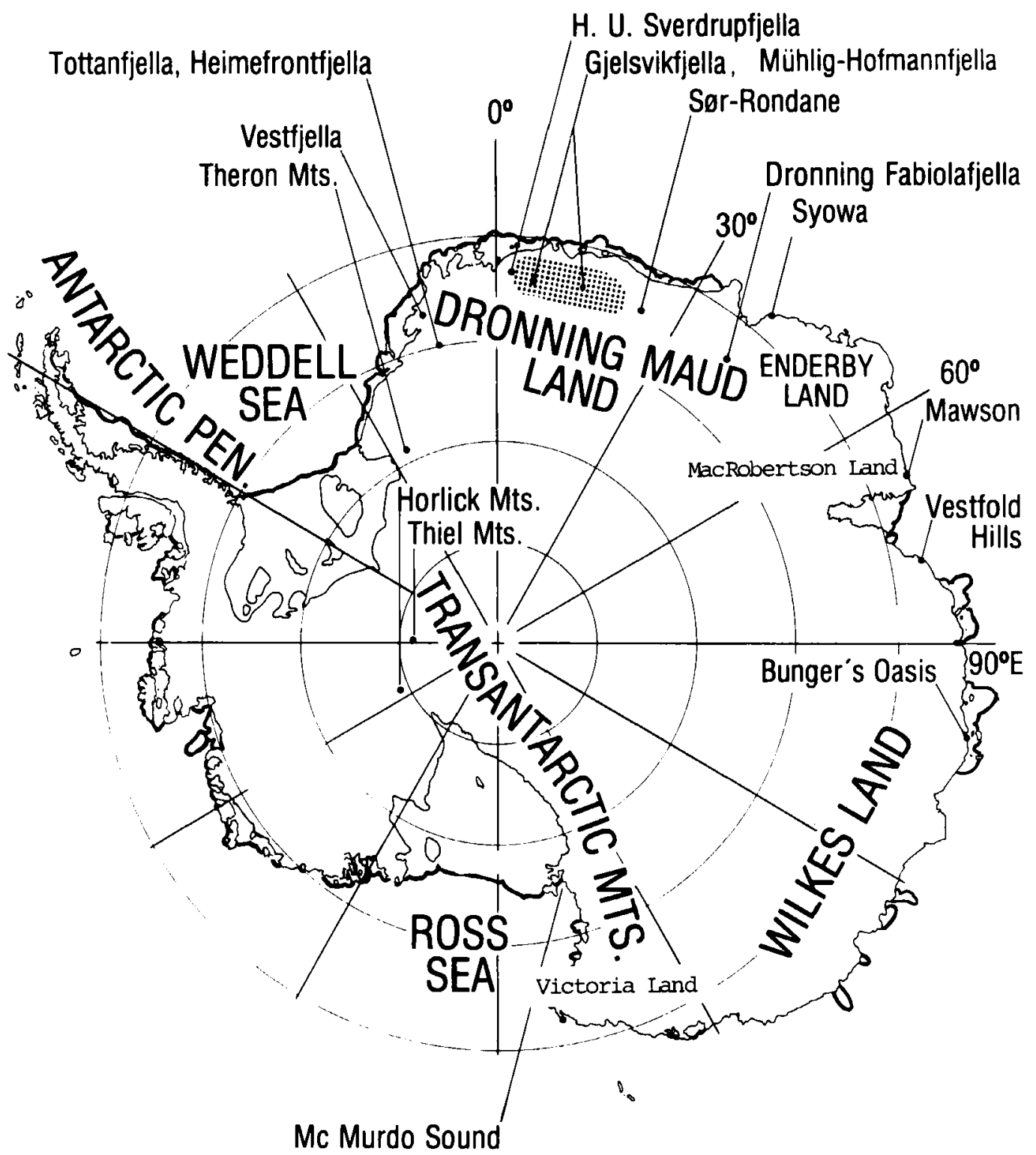

Fig. 1. Antarctica, location map. Stippled: Gjelsvikfjella and Mühlig-Hofmannfjella. Thick coastal outline: Margin of floating ice shelves.

Few, if any, botanists have visited the interior mountains of Dronning Maud Land. However, comprehensive ecological studies have been performed at some permanent stations; for review, see MacNamara (1973) and Matsuda \& Hoshai (1979). Other observation and collecting work was done by various British or Norwegian expeditions (see Lindsay $(1971,1972)$, Øvstedal (1983a, b), and Engelskjøn (1985)).

\section{Objectives of the present study}

The work in progress aims at a combined floristic and field ecological description of a continental Antarctic mountain environment. The available collections of cyanophyceans, algae, lichens and bryophytes will be used for comparison with flora and vegetation to the $W$ and $E$ of the study area, when their identification has been completed in cooperation with various specialists. 


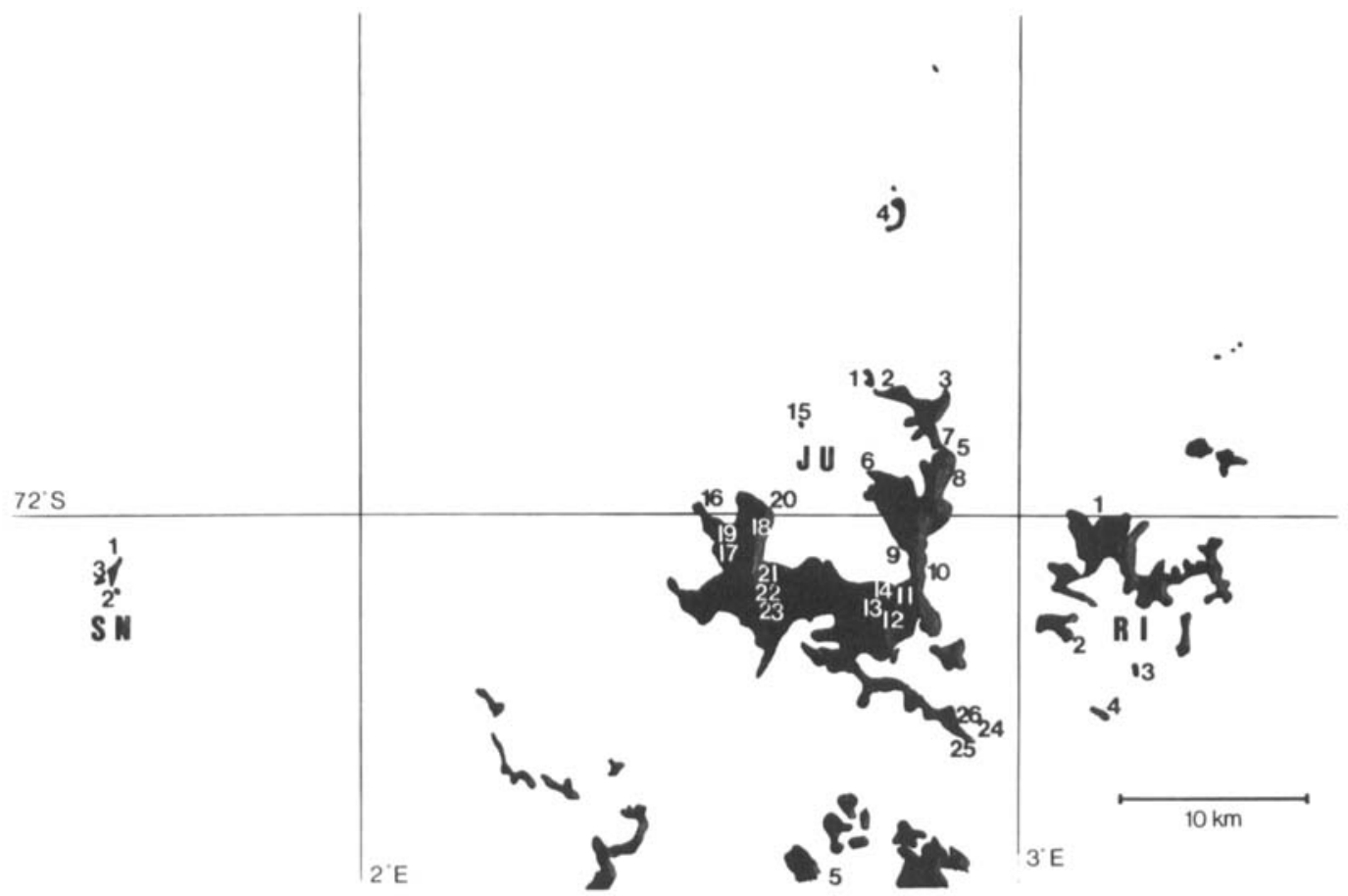

Fig. 2A. Survey map, Gjelsvikfjella and easternmost outlier of H. U. Sverdrupfjella. Legend, see Table 1.

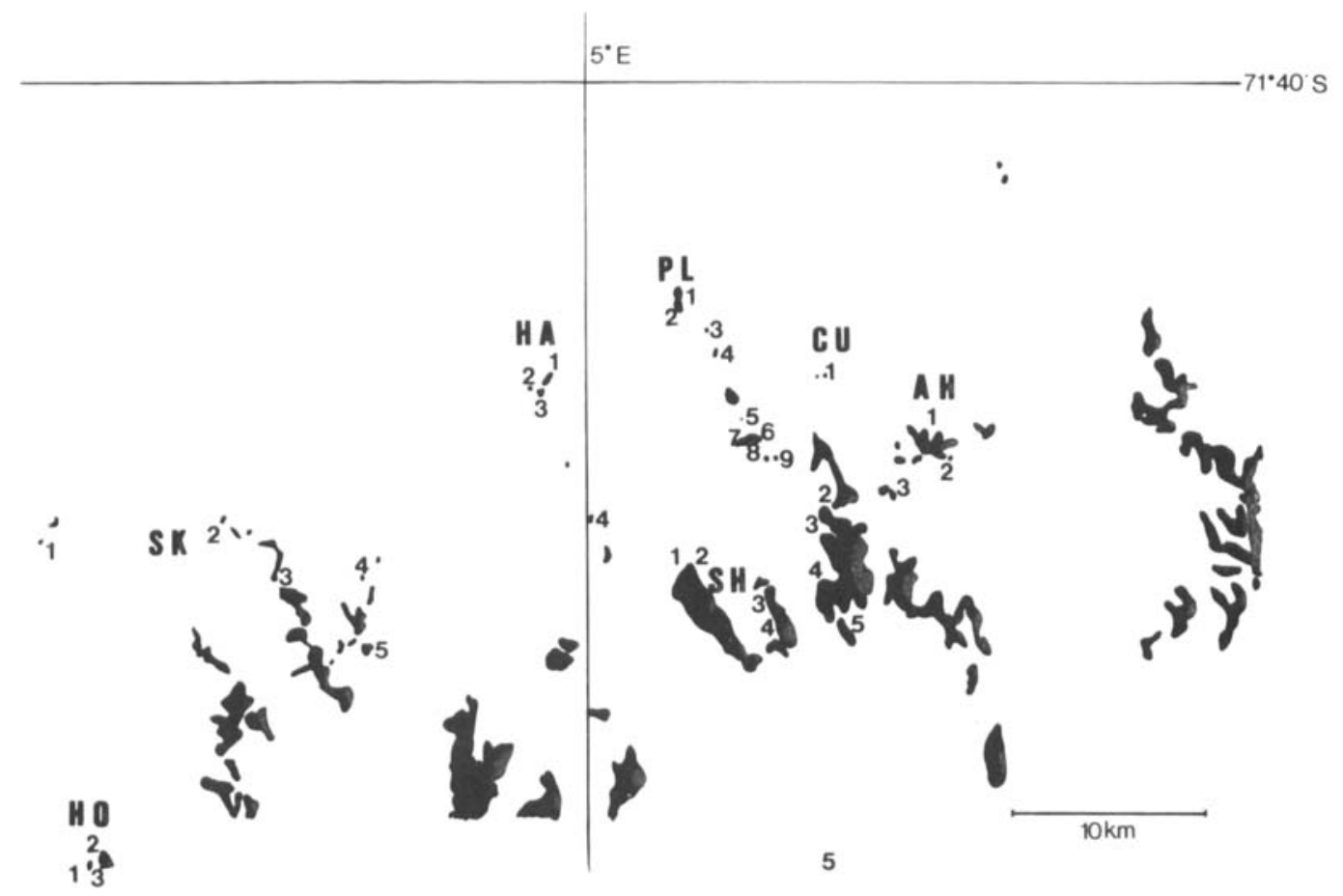

Fig. $2 B$. Survey map, Mühlig-Hofmannfjella between $4^{\circ}$ and $6^{\circ} \mathrm{E}$. Legend, see Table 1 . 
Representative material of these groups now offers a specimen base for taxonomic revision. As has been repeatedly noted (cf. Smith 1984, p. 77) the complicated taxonomic state of most cryptogamic groups in the Antarctic precludes a thorough assessment of their distribution and ecological significance.

Ecological studies in Antarctic alpine environments have been few (Siple 1938; Bowra et al. 1966; Ugolini \& Starkey 1966; Ugolini 1977; Kappen 1985a, b), and extensive sectors of the Antarctic slope remain unexplored (Smith 1984, p. 64). The prevailing climatic and ice conditions impede field work, particularly in the Antarctic autumn. The present contribution aims at summarizing ecological features of the study area in relation to the local development of the Antarctic cold desert cryptogam formation (Aleksandrova 1980).

\section{Situation and topography}

The survey maps (Fig. 2A, B) show the location of 68 sites which were visited for botanical inves- tigation in January and February 1985. Placenames and elevations in $\mathrm{m}$ above sea level are provided in Table 1.

The Gjelsvikfjella Mountains (Fig. 2A) are situated $220 \mathrm{~km}$ from the ice shelf margin and $100 \mathrm{~km}$ inside the hinge line of the ice shelf. Their highest parts are at Risemedet, comprising summits between 2,471 and $2,704 \mathrm{~m}$ a.s.l. (Fig. 3) and at Terningskarvet, $2,678 \mathrm{~m}$ a.s.l. The lowest exposed ground is in the bottom of the Jutulsessen amphitheatre, $1,080 \mathrm{~m}$ a.s.l., which is the most extensive non-glaciated area on this part of the Antarctic slope (Fig. 4).

The Mühlig-Hofmannfjella mountains (Fig. 2B) run from west to east approx. $200 \mathrm{~km}$ from the ice shelf margin and $130 \mathrm{~km}$ inside the hinge line. Their highest summits are Kyrkjeskipet, $3,083 \mathrm{~m}$, and Gessnertind, 3,020 $\mathrm{m}$ a.s.l. The lowest rock exposures are the nunataks to the north, 1,334 to $1,661 \mathrm{~m}$ a.s.l. (Fig. 5). Due to higher elevation and closeness to the Antarctic ice plateau, the interior parts of MühligHofmannfjella (Figs. 6, 7, 8) experience a more severe climate than e.g. Jutulsessen in Gjelsvikfjella.

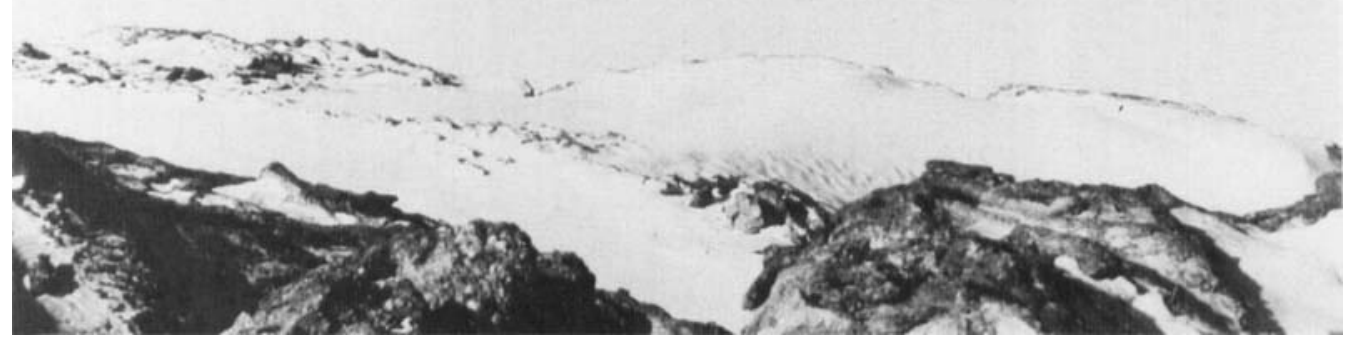

Fig. 3. The nunatak Horten, $2,471 \mathrm{~m}$ a.s.1. (locality no. RI 3) in Gjelsvikfjella, one of the highest elevations visited. In front, icescoured rocks on summit $2,188 \mathrm{~m}$ a.s.l. (RI 4). 29 January 1985. 
Table 1. Localities visited for botanical investigation and collecting in Gjelsvikfjella, H. U. Sverdrupfjella and Mühlig-Hofmannfjella by members of the Camp Norway 5 party. Altitudes in $m$ above sea level.

SN Snarbynuten (Fig. 2A)

1-3 Various nunataks, $1570-1610$

JU Jutulsessen area (Fig. 2A, 4, 9)

1-3 Stabben, 1200-1600

4 Rabben, $1300-1432$

5-8 Armlenet, 1150-1550

9-11 Jutulhogget, 1080-1600

12-14 S cirque and Brugda, 1080-1600

15 Nunatak $1170 \mathrm{~m}, 1160-1170$

16-20 Grjotlia, $1100-1700$

21-23 SW cirque, 1120-1500

24-26 Brugda SE part, 1990-2150

RI Risemedet-Terningen area (Fig, 2A, 3)

1 Medmulen, 1500

2 Nunatak NW of summit $2188 \mathrm{~m}, 2050$

3 Horten, 2450-2471

4 Summit $2188 \mathrm{~m}, 2160-2188$

5 Terningskarvet, $2550-2678$

HO Hoggestabben area (Fig. 2B, 6)

1 Småsponen, 1700

2-3 Below Hoggestabben, 1650
SK Skigarden area (Fig. 2B, 7, 8)

1 Larsgaddane SW, 1630-1650

2-3 Skigarden, 1600-1650

4-5 Bjørnesaksa, 1620-1850

HA Hamarskaftet nunatak group (Fig. 2B)

1-4 Various nunataks, 1580-1661

PL Plogskaftet nunatak group (Fig. 2B, 5)

1-9 Various nunataks, $1530-1680$

SH Svarthamaren area (Fig. 2B)

1-2 Svarthamaren, 1590-1610

3-4 Båsbolken, 1620-1650

5 Skorvetangen, $2600-2680$

CU Cumulusfiellet - Breplogen area (Fig. 2B, 5)

1 Nunatak $N$ of Cumulusfjellet, 1550-1570

2 Cumulusfjellet, 1800-1820

3-4 Høgsenga, 1650-1700

5 Breplogen, 2600-2695

AH Ahlstadhottane area (Fig. 2B)

1 Crest E of summit 2065, 1920

2-3 Various nunataks, $1700-1820$

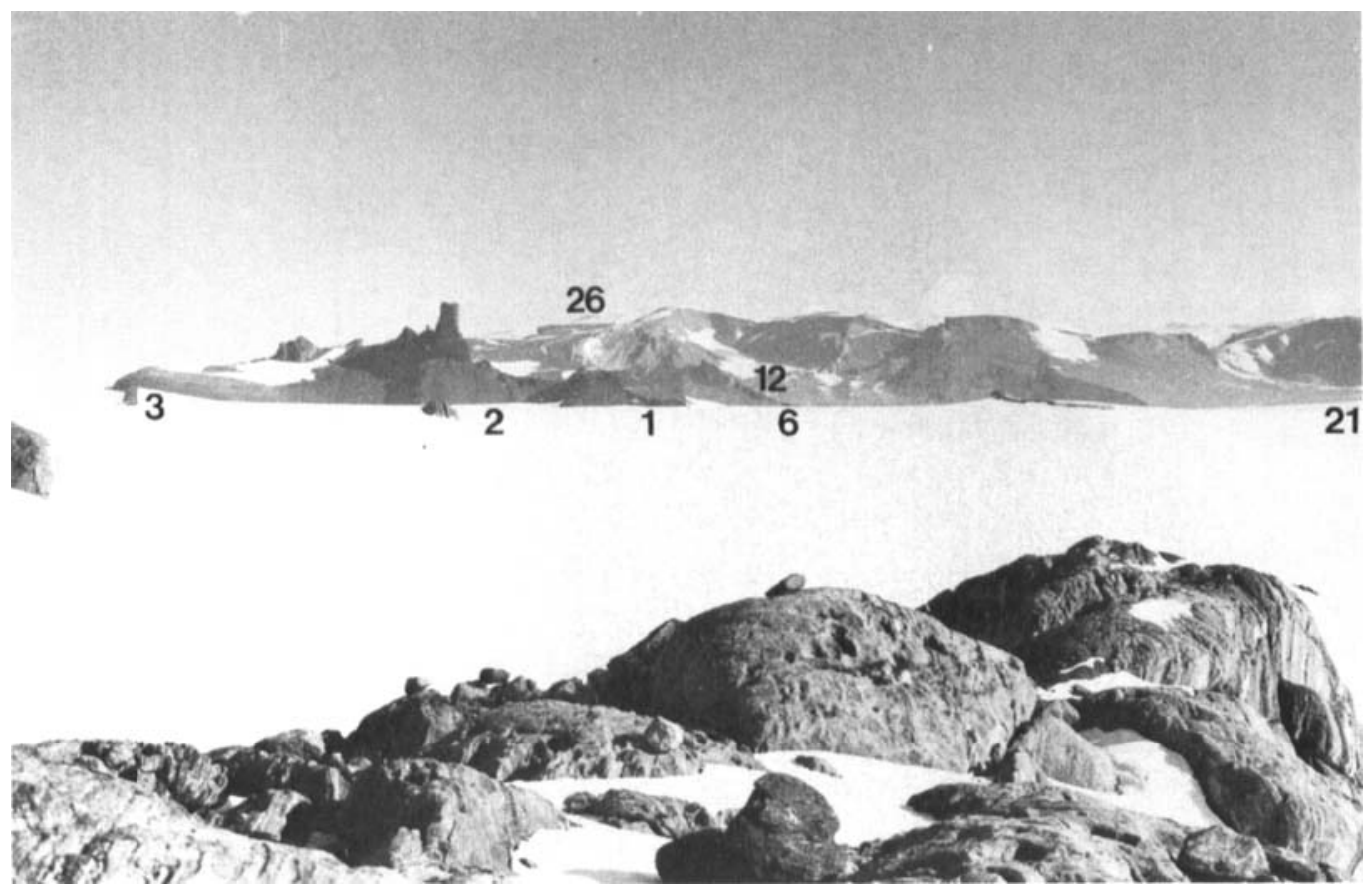

Fig. 4. The Jutulsessen amphitheatre (JU) from Rabben (JU 4). Summit of Stabben (1,887 m a.s.l.), and other localities identified by numbers, cf. Table 1 . In front, ice-scoured gneissic rocks with small cavitation hollows. 19 January 1985. 


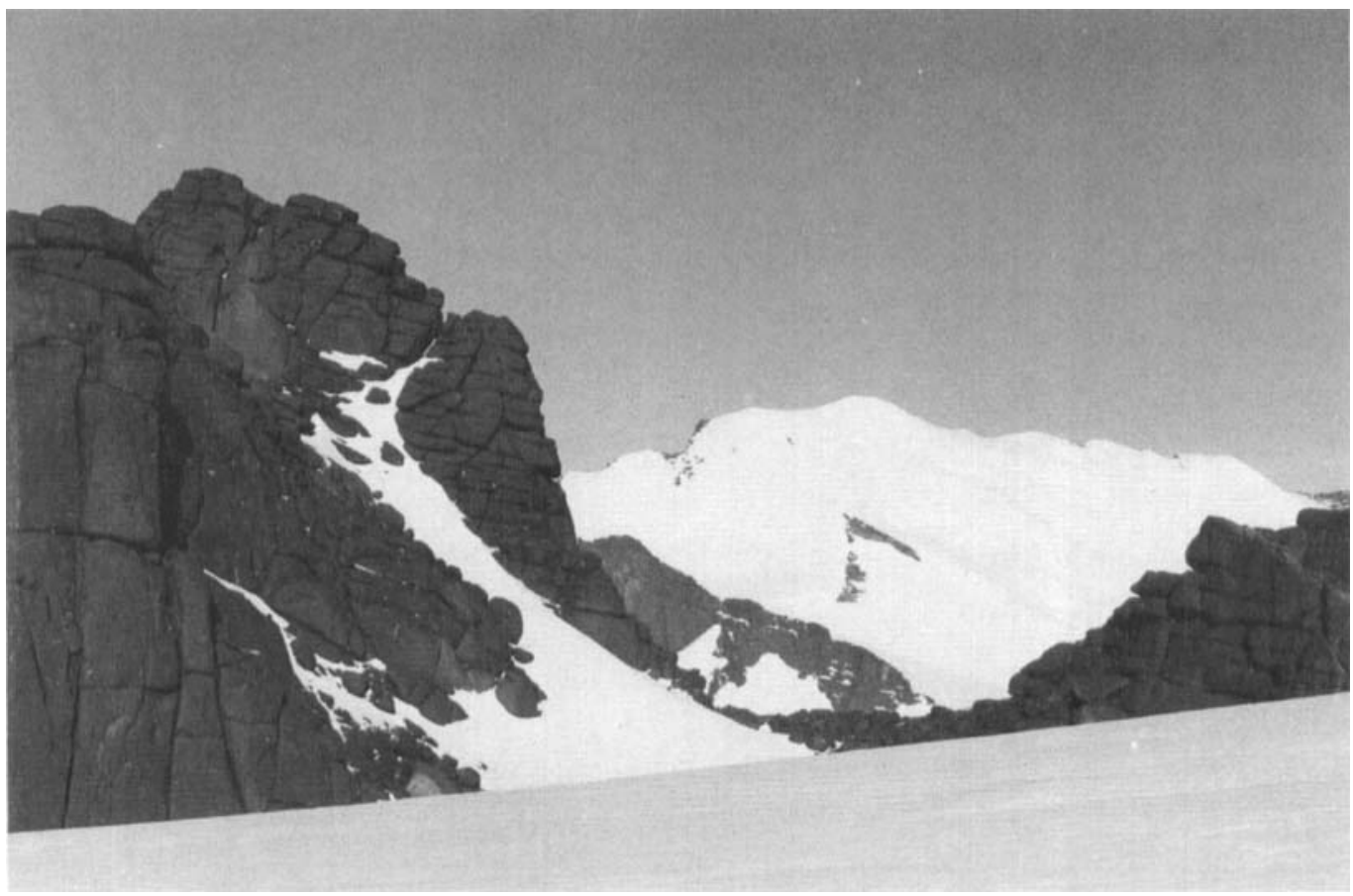

Fig. 5. Cliffs of charnockite (bipyroxene syenite) at Plogskaftet, Mühlig-Hofmannfjella, approx. 1,700 m a.s.l. (PL 9). Behind, Cumulusfjellet $(2,333 \mathrm{~m}$ a.s.l.), glacier-covered. Generally barren rocks with some crusts of Xanthoria elegans. 9 February 1985.

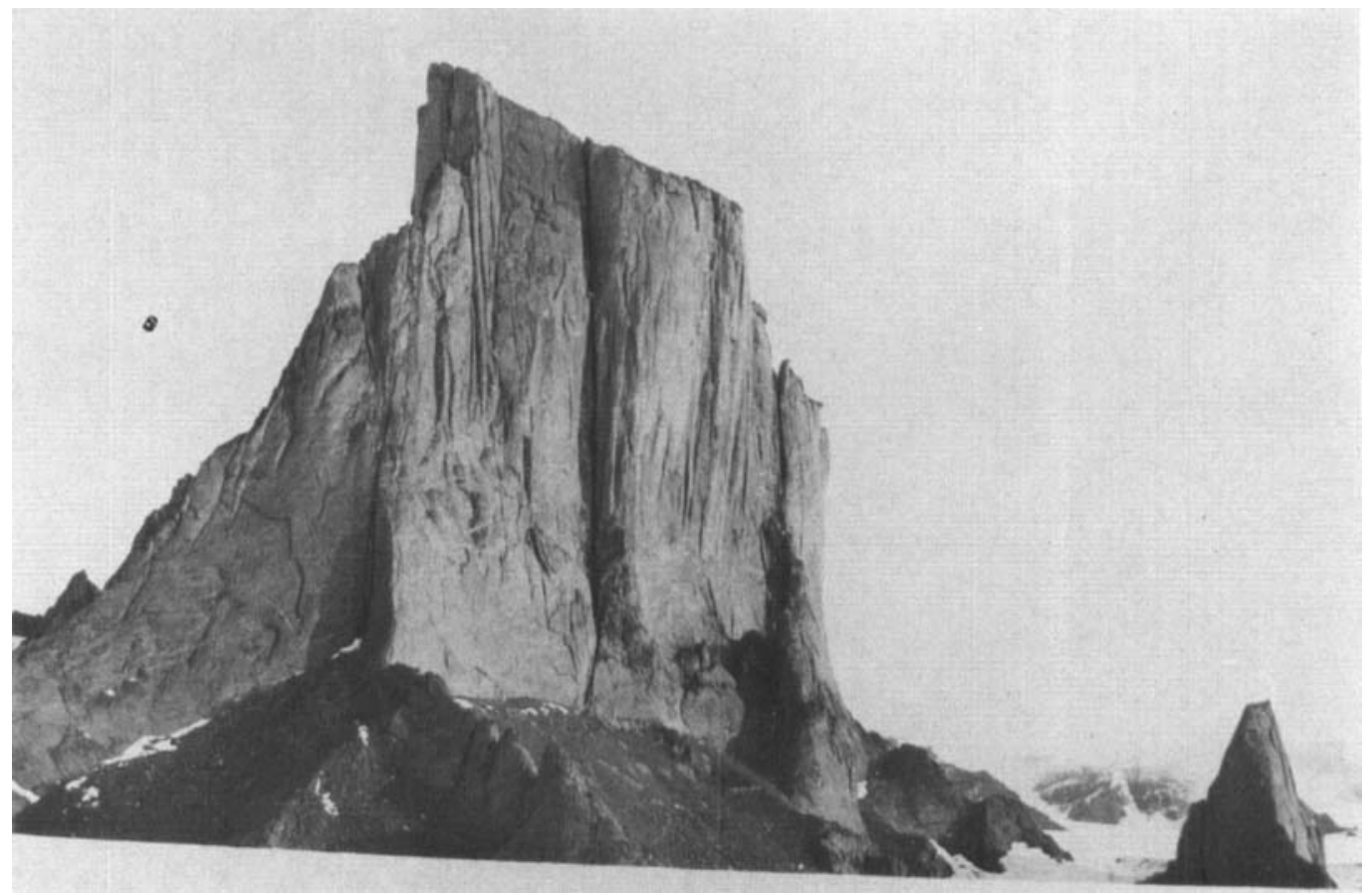

Fig. 6. Hoggestabben and Småsponen, Mühlig-Hofmannfjella (HO). Hornblende granite, supporting rich moss and lichen vegetation at base. 1 February 1985. 


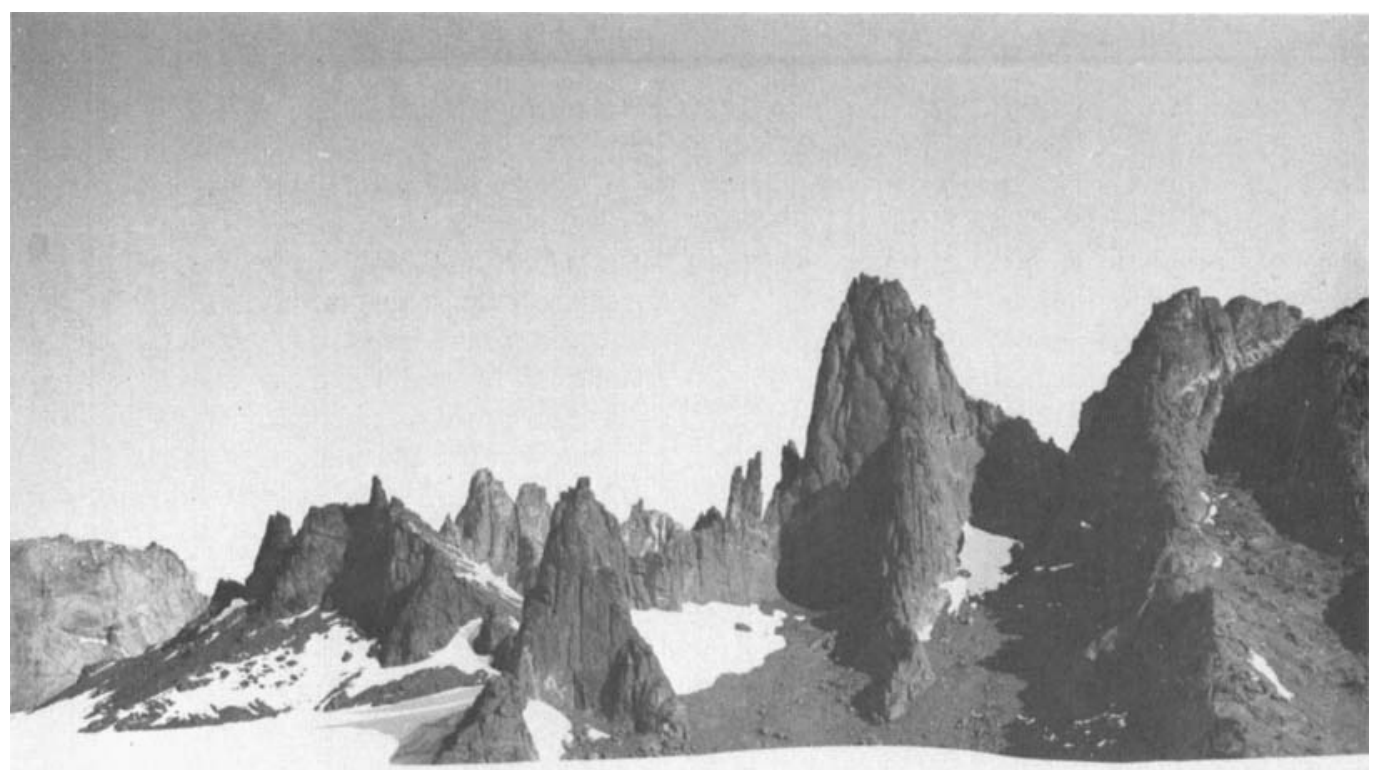

Fig. 7. The pinnacles of Skigarden (1,970 m a.s.l.), Mühlig-Hofmannfjella (SK 3). Coarse screes and cliffs of dark charnockite, largely devoid of vegetation. 10 February 1985.

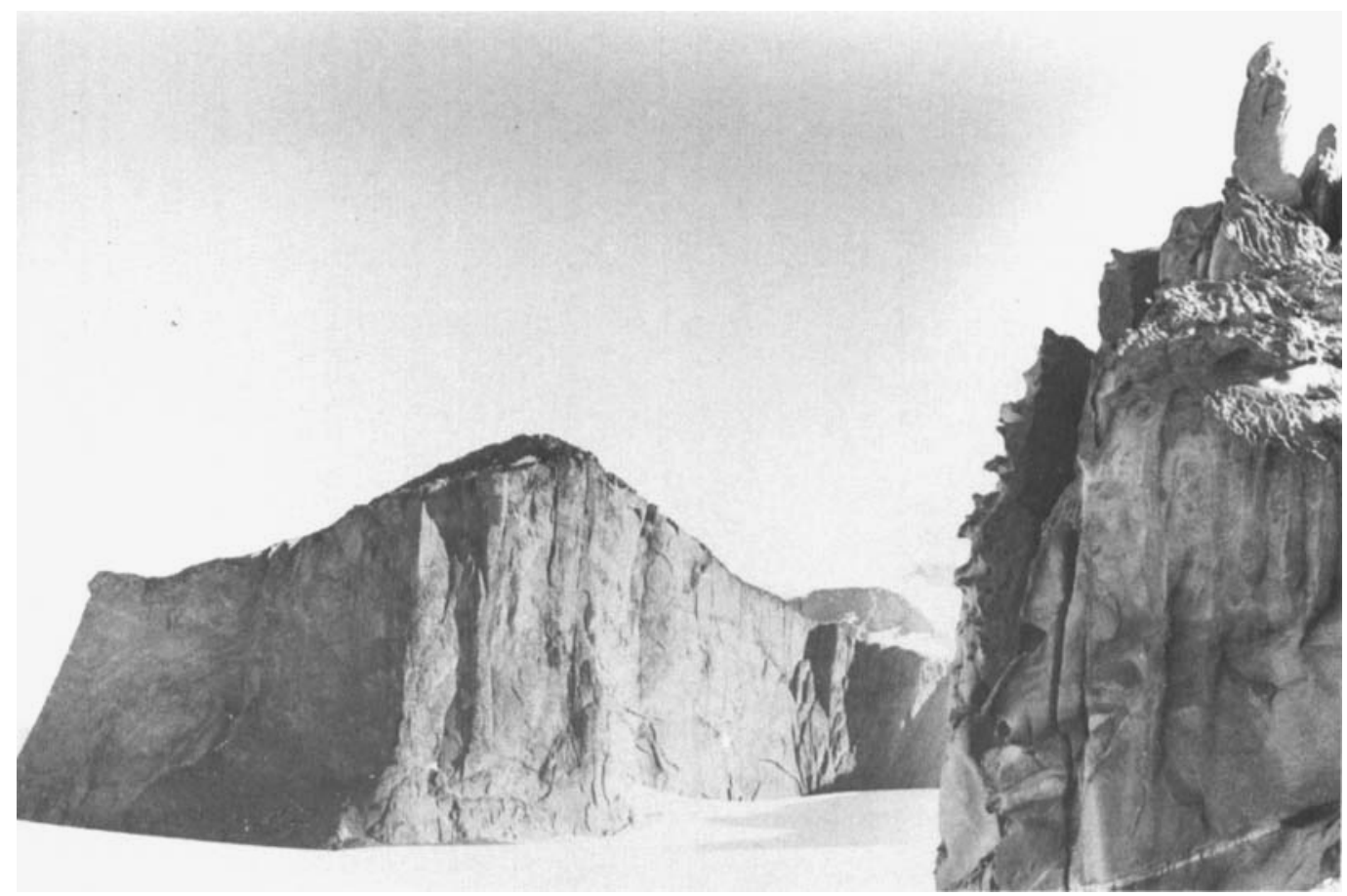

Fig. 8. Nameless nunataks SE of Bjørnesaksa, Mühlig-Hofmannfjella (SK 5), approx. 1,800-2,220 m a.s.l. Honeycomb weathering and cavitation hollows in medium-grained charnockite. 10 February 1985. 


\section{Bedrock and derived soils}

The mountains of Gjelsvikfjella and Mühlig-Hofmannfjella are built of an Archean basement complex of gneiss and charnockite (Ravich \& Soloviev 1966; Ohta \& Tørudbakken 1985). The metamorphism ranges from amphibolite facies in the west to mainly granulite facies in the east. The lithology varies from granitic to gabbroid.

The texture and weathering of rocks vary in a way significant to vegetation. Charnockites yield a rugged surface of protruding feldspars, whereas the gneisses have smoother surfaces more suitable for lichen growth. Biotite-pyroxene rocks and dolerite dykes are dark coloured and effective in absorbing radiation (Table 7).

A conspicuous feature of wind-exposed cliffs is the honeycomb and cavitation weathering (van
Autenboer 1964; Juckes 1969; Worsfold 1967). Such hollows may be up to $2 \mathrm{~m}$ across (Fig. 8), and are prone to accumulate snow and meltwater. They often support cyanophycean and lichen growth in sites which are generally barren because of wind exposure and drought.

Chemical analyses of weathering soils of various bedrock derivation are presented in Table 2 , and the impact of birds and evaporation on soils is indicated by analyses in Table 3 .

Lithosol derived from feldspar-rich bedrock, e.g. charnockite and migmatite (Table 2-I) all show a pH below 7 and modest amounts of $\mathrm{Ca}$ and $\mathrm{Mg}$.

Lithosol derived from the biotite-pyroxene rocks prevailing in parts of Jutulsessen (Table 2 II) has mean $\mathrm{pH}$ values above 7 , and high content of $\mathrm{Ca}, \mathrm{K}$ and $\mathrm{Mg}$. An exception is sample no. 10

Table 2. Weathering soils from Gjelsvikfjella and Mühlig-Hofmannfjella. Analyses of pH and some elements.

\begin{tabular}{|c|c|c|c|c|c|c|c|}
\hline & & $\begin{array}{l}\text { Elevation } \\
\text { m a.s.1. }\end{array}$ & $\mathrm{pH}$ & $\begin{array}{l}\mathrm{Ca}-\mathrm{Al} \\
\mathrm{mg} / 10 \mathrm{~g}_{\mathrm{g}}\end{array}$ & $\begin{array}{l}\mathrm{CaO} \\
\%\end{array}$ & $\begin{array}{l}\mathrm{Mg}-\mathrm{AL} \\
\mathrm{mg} / 100 \mathrm{~g}\end{array}$ & $\begin{array}{l}\mathrm{K}-\mathrm{AL} \\
\mathrm{mg} / 100 \mathrm{~g}\end{array}$ \\
\hline \multicolumn{8}{|l|}{ I } \\
\hline \multirow{3}{*}{$\begin{array}{l}\text { Lithosol, derived } \\
\text { from migmatite and } \\
\text { charnockite }\end{array}$} & $\begin{array}{l}\text { 1. Gneiss NNW Stabben, } \\
\text { with Grimmia lawiana }\end{array}$ & 1450 & 6.1 & 80 & 0.25 & 3.6 & 3.5 \\
\hline & $\begin{array}{l}\text { 4. Charnockite, Bjørnesaksa, } \\
\text { with Rhizoplaca melan- } \\
\text { ophthalma }\end{array}$ & 1625 & 6.6 & 90 & 0.67 & 3.8 & 4.1 \\
\hline & $\begin{array}{l}\text { 9. Charnockite, Básbolken, } \\
\text { cavitation hollow, with } \\
\text { Nostoc sp. }\end{array}$ & 1620 & 5.7 & 50 & 0.16 & 2.0 & 2.1 \\
\hline Average of I & & & 6.1 & 73 & 0.36 & 3.1 & 3.2 \\
\hline \multicolumn{8}{|l|}{ II } \\
\hline \multirow{4}{*}{$\begin{array}{l}\text { Lithosol, derived } \\
\text { from biotite- } \\
\text { pyroxene rock, all } \\
\text { from the Stabben } \\
\text { area }\end{array}$} & $\begin{array}{l}\text { 3. Stabben, Xanthoria } \\
\text { elegans-Candelariella } \\
\text { hallenensis-Nostoc soc. }\end{array}$ & 1350 & 8.7 & 115 & 2.00 & 20 & 22 \\
\hline & $\begin{array}{l}\text { 5. Stabben, sterile and } \\
\text { evaporite-encrusted } \\
\text { gravel (Fig. 9) }\end{array}$ & 1400 & 7.7 & 388 & 2.87 & 90 & 15 \\
\hline & $\begin{array}{l}\text { 7. Loamy detritus, with } \\
\text { Sarconeurum glaciale }\end{array}$ & 1360 & 7.5 & 140 & 2.66 & 9.2 & 9.6 \\
\hline & $\begin{array}{l}\text { 10. Wet gravel below snow, } \\
\text { with Nostoc sp. and } \\
\text { Phormidium sp. }\end{array}$ & 1370 & 6.5 & 80 & 4.48 & 5.4 & 2.6 \\
\hline Average of II & & & 7.6 & 181 & 3.00 & 31 & 12.3 \\
\hline \multicolumn{8}{|l|}{ III } \\
\hline \multirow[t]{2}{*}{$\begin{array}{l}\text { Redeposited, } \\
\text { polymictic sediments }\end{array}$} & $\begin{array}{l}\text { 6. Jutulsessen, sandy } \\
\text { deposit by a runnel, } \\
\text { with Sarconeurum glaciale }\end{array}$ & 1100 & 7.2 & 75 & 0.39 & 4.8 & 4.8 \\
\hline & $\begin{array}{l}\text { 8. Moraine gravel NW of } \\
\text { Armlenet, Nostoc soc. } \\
\text { (c. Table 9-II) }\end{array}$ & 1160 & 6.1 & 65 & 0.39 & 2.2 & 2.3 \\
\hline Average of III & & & 6.7 & 70 & 0.39 & 3.5 & 3.6 \\
\hline
\end{tabular}


Table 3. Some markers of biogenic or evaporative influence on soil chemistry, Gjelsvikfjella and Mühlig-Hofmannfjella.

\begin{tabular}{llllll}
\hline & $\begin{array}{l}\text { Elevation } \\
\text { m a.s.l. }\end{array}$ & $\mathrm{pH}$ & $\begin{array}{l}\mathrm{P}-\mathrm{AL} \\
\mathrm{mg} / 100 \mathrm{~g}\end{array}$ & $\begin{array}{l}\text { Total N } \\
\%\end{array}$ & $\begin{array}{l}\mathrm{Na} \\
\mathrm{mg} / 100 \mathrm{~g}\end{array}$ \\
\hline $\begin{array}{l}\text { 1. Charnockite lithosol } \\
\text { below petrel rookery, } \\
\begin{array}{l}\text { Svarthamaren } \\
\text { Charnockite lithosol, }\end{array}\end{array}$ & 1630 & 7.2 & 40 & 0.09 & 11 \\
$\begin{array}{l}\text { no bird influence, } \\
\text { Bjørnesaksa }\end{array}$ & 1625 & 6.6 & 1.0 & 0.03 & 3.5 \\
$\begin{array}{l}\text { 5. Evaporite-encrusted } \\
\text { gravel, sterile, } \\
\text { Stabben (Fig. 9) }\end{array}$ & 1400 & 7.7 & 6.0 & Not \\
\hline
\end{tabular}

which was leached by meltwater from a snowdrift. No. 5 had a superficial evaporite crust (Fig. 9) and was enriched with metallic cations, including $\mathrm{Na}$ (Table 3 ), which is a frequent phenomenon in arid tracts of Antarctica (Claridge \& Campbell 1977).

The sandy deposits (Table 2-III) show varying $\mathrm{pH}$, presumably due to polymictic bedrock derivation and exposure to leaching.

The biogenic impact on soils was studied in a few samples (Table 3). Nos. 1 and 2 are derived from coarse charnockite of similar mineral com- position, but the lithosol from the periphery of a sloping petrel nesting area shows a remarkable enrichment of $\mathrm{P}$, partly also of $\mathrm{Na}$, which was expected (see Ugolini 1972, p. 188).

\section{Climate and hydrology}

\section{General climatic conditions}

The study area is part of the Antarctic slope, i.e. the mountain and glacier zone inland from the

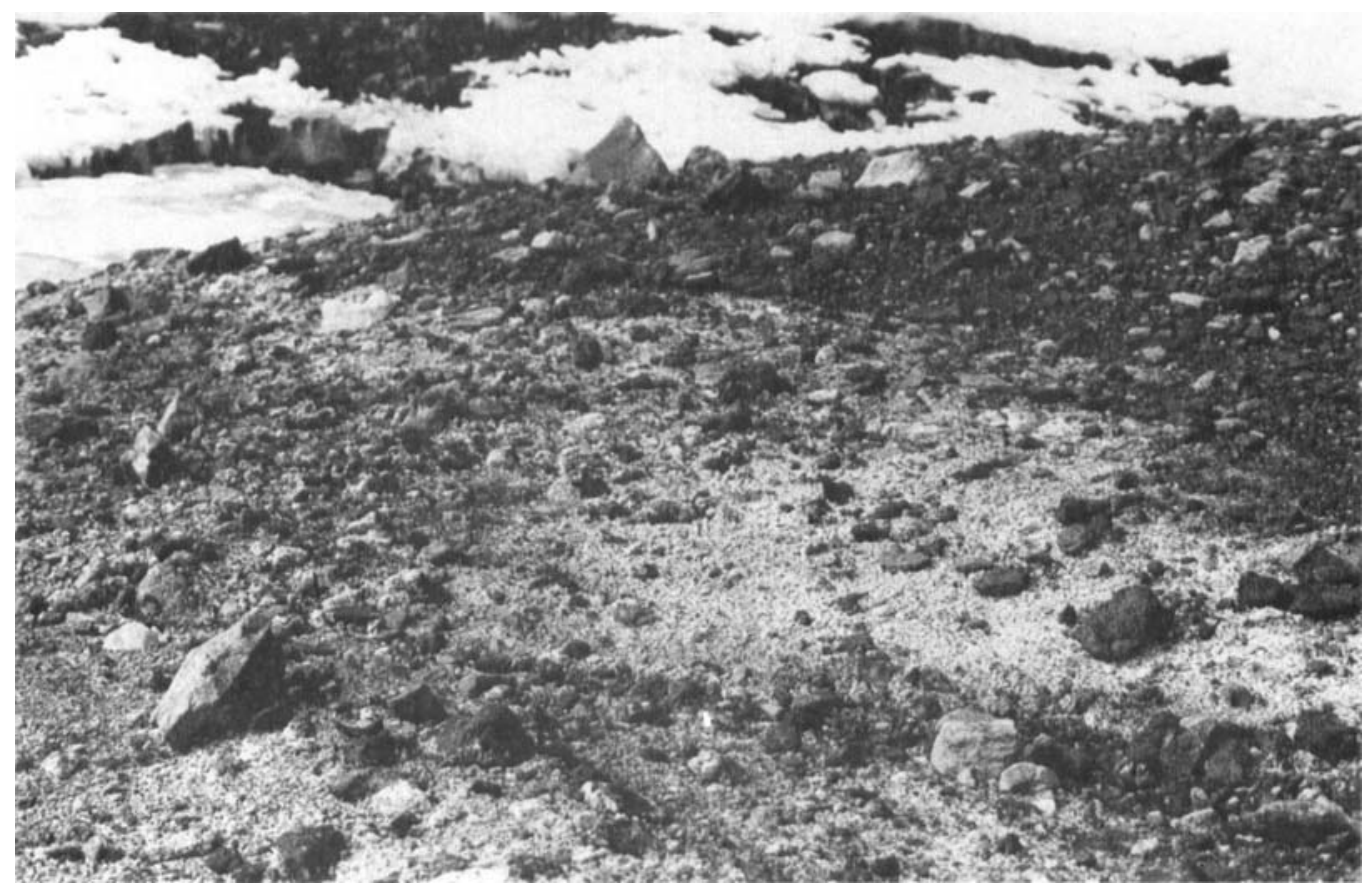

Fig. 9. Evaporite-encrusted lithosol on biotite-pyroxene rock, below Stabben in Jutulsessen (JU 2), 1,400 m a.s.1. Sublimating snow-drift in the background, cf. Table 2. 20 January 1985. 


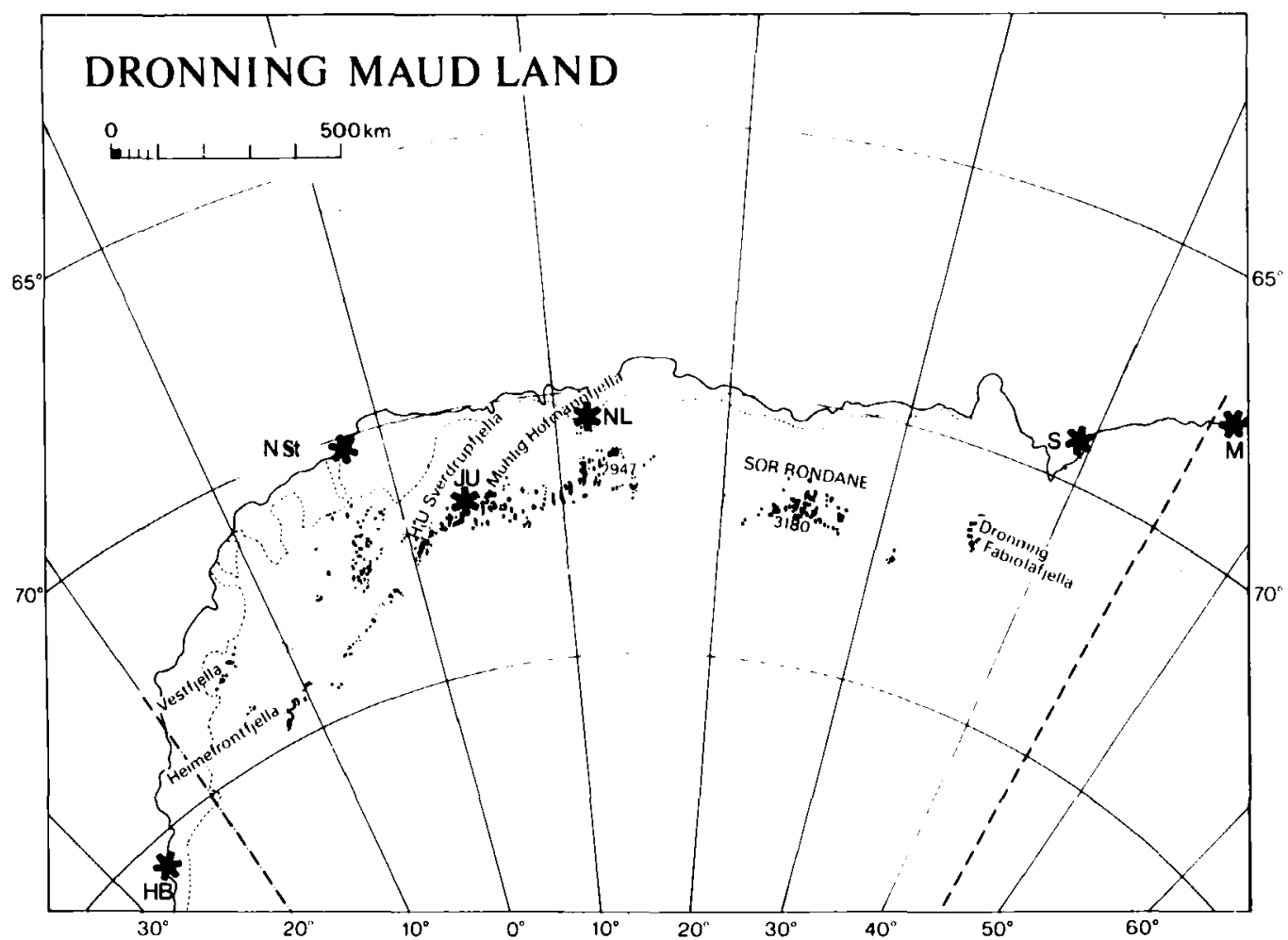

Fig. 10. Extent of exposed ground in Dronning Maud Land, and location of meteorological stations. HB: Halley Bay, NSt: Norway Station, JU: Jutulsessen (Gjelsvikfjella) - automatic station operating since 1985, NL: Novolazarevskaya, S: Syowa Station, M: Molodezhnaya.

Antarctic floating ice shelf. It includes some nunataks on the central glacier plateau of the Antarctic ice sheet; in the following account this is referred to as the Polar plateau.

The climate is of the high-polar ice-cap type, characterized by subzero summer and autumn temperatures - a state of perpetual frost, and dark and cold winters. Such a climate has been classified by Köppen and Geiger (1936) as 'EH' and by Troll and Paffen as ' $I_{1}$ ' (see map in Blüthgen \& Weischet 1980).

Average temperatures for stations on the coast of Greater Antarctica (Figs. 1, 10) are summarized in Table 4, some additional parameters of climatological importance in Table 5. Very few observations are available from mountains on the Antarctic slope. The temperature estimates entered in Table 6 are based on observations at Camp Norway 5 from 14 January to 14 February 1985 , assuming a vertical air temperature gradient of $0.65^{\circ} / 100 \mathrm{~m}$. The summer months of January and December have similar temperatures.

The water equivalent of snowfall decreases from approx. $400 \mathrm{~mm}$ annually on the coast of

Table 4. Average monthly air temperatures, annual means, and amplitudes (A) for some stations in Greater Antarctica. Data compiled from Müller (1982).

\begin{tabular}{llclllllrr}
\hline Station & Lat. & Long. & Altitude & \multicolumn{3}{c}{ Monthly mean temperatures } & \multirow{2}{*}{ Year } & A \\
& & & m a.s.l. & July & Dec. & Jan. & Feb. & \\
\hline General Belgrano & $77^{\circ} 58^{\prime} \mathrm{S}$ & $38^{\circ} 48^{\prime} \mathrm{W}$ & 50 & -32.7 & -6.0 & -6.0 & -13.2 & -22.3 & 26.7 \\
& & & & & & & & & \\
Halley Bay & $75^{\circ} 30^{\prime} \mathrm{S}$ & $26^{\circ} 39^{\prime} \mathrm{W}$ & 30 & -27.5 & -5.7 & -5.0 & -10.0 & -18.7 & 22.5 \\
Norway Station & $70^{\circ} 30^{\prime} \mathrm{S}$ & $3^{\circ} 32^{\prime} \mathrm{W}$ & 56 & -26.1 & -5.2 & -4.4 & -8.9 & -17.2 & 21.7 \\
Novolazarevskaja & $70^{\circ} 46^{\prime} \mathrm{S}$ & $11^{\circ} 49^{\prime} \mathrm{E}$ & 87 & -17.9 & -0.8 & -1.2 & -3.9 & -10.8 & 17.1 \\
Syowa Base & $69^{\circ} 00^{\prime} \mathrm{S}$ & $39^{\circ} 35^{\prime} \mathrm{E}$ & 15 & -18.2 & -1.7 & -1.0 & -3.5 & -10.7 & 17.2 \\
Mawson & $67^{\circ} 36^{\prime} \mathrm{S}$ & $62^{\circ} 53^{\prime} \mathrm{E}$ & 8 & -17.6 & -0.4 & -0.2 & -4.2 & -11.2 & 17.4 \\
\hline
\end{tabular}


Table 5. Some biologically important climatic parameters for stations in Greater Antarctica. Data compiled from Müller (1982). Wind chill/cooling power according to Siple \& Passel (1945) and Vinje (1962).

\begin{tabular}{llllllr}
\hline Station & $\begin{array}{l}\text { Degree-Days } \\
\text { Dec.-Jan. } \\
\text { (DD-2) }\end{array}$ & $\begin{array}{l}\text { Sunshine } \\
\text { hours, } \\
\text { annual }\end{array}$ & July & Wind chill/cooling power, monthly \\
& December & January & February \\
\hline General Belgrano & -370 & No record & $1938 / 68$ & $1009 / 32$ & $1009 / 32$ & $1238 / 40$ \\
Halley Bay & -330 & 1359 & $1693 / 56$ & $1042 / 34$ & $1034 / 34$ & $1176 / 39$ \\
Norway Station & -300 & 1389 & $1824 / 69$ & $1112 / 40$ & $1088 / 39$ & $1251 / 46$ \\
Novolazarevskaja & -60 & No record & $1654 / 72$ & $1027 / 40$ & $1036 / 40$ & $1177 / 50$ \\
Syowa Base & -85 & 1849 & $1515 / 54$ & $967 / 33$ & $934 / 31$ & $988 / 32$ \\
Mawson & -20 & 1795 & $1670 / 76$ & $1056 / 44$ & $1041 / 43$ & $1211 / 55$ \\
\hline
\end{tabular}

Table 6. Some temperature estimations $\left({ }^{\circ} \mathrm{C}\right.$ ) from various elevations in Gjelsvikfjella and Mühlig-Hofmannfjella compared with averages for the most southerly stations in Antarctica.

\begin{tabular}{|c|c|c|c|c|c|c|c|}
\hline \multirow[t]{2}{*}{ Area/Station } & \multirow[t]{2}{*}{ Lat. } & \multirow[t]{2}{*}{ Long. } & \multirow[t]{2}{*}{$\begin{array}{l}\text { Altitude } \\
\text { m a.s.l. }\end{array}$} & Average & onthly ten & ratures & \multirow{2}{*}{$\begin{array}{l}\text { Degree-Days } \\
\text { Dec.-Jan. } \\
\text { (DD-2) }\end{array}$} \\
\hline & & & & December & January & February & \\
\hline \multicolumn{8}{|l|}{ Gjelsvikfjella: } \\
\hline $\begin{array}{l}\text { Jutulsessen NE part } \\
\text { Mühlig-Hofmannfjella: } \\
\text { Svarthamaren Camp }\end{array}$ & $71^{\circ} 55^{\prime} \mathrm{S}$ & $2^{\circ} 45^{\prime} \mathrm{E}$ & 1200 & -5 & -5 & -9 & -300 \\
\hline Norway 5 & $71^{\circ} 55^{\prime} \mathrm{S}$ & $5^{\circ} 10^{\prime} \mathrm{E}$ & 1600 & -8 & -8 & -12 & -500 \\
\hline \multicolumn{8}{|l|}{ Gjelsvikfjella: } \\
\hline Risemedet: Horten & $72^{\circ} 05^{\prime} \mathrm{S}$ & $3^{\circ} 10^{\prime} \mathrm{E}$ & 2400 & -13 & -13 & -17 & -800 \\
\hline McMurdo & $77^{\circ} 53^{\prime} \mathrm{S}$ & $166^{\circ} 44^{\prime} \mathrm{E}$ & 24 & -3.8 & -3.4 & -8.3 & -225 \\
\hline Vostok & $78^{\circ} 28^{\prime} \mathrm{S}$ & $106^{\circ} 48^{\prime} \mathrm{E}$ & 3488 & -32.7 & -33.4 & -44.2 & -2050 \\
\hline South Pole & $90^{\circ} \mathrm{S}$ & - & 2800 & -28.1 & -28.8 & -40.1 & -1765 \\
\hline
\end{tabular}

Dronning Maud Land to approx. $100 \mathrm{~mm}$ on the outer parts of the Polar plateau (Blüthgen \& Weischet 1980).

Environmental factors which contribute to a special mountain climate include the modest cloud cover, high altitude, and intensive solar radiation (cf. Table 7). The summit 2,188 $\mathrm{m}$ a.s.l. (locality no. RI 4) south-west of the mountain Horten in Gjelsvikfjella (Fig. 3) experiences low ambient air temperatures, but measurements with an infrared temperature recorder showed that surface temperatures reached between 12 and $23^{\circ} \mathrm{C}$ on optimally inclined, north-facing rocks when the air temperature was $-10^{\circ} \mathrm{C}$. Southfacing rocks are less heated and usually devoid of vegetation. The colour of rocks is also important, dark rock attaining a surface temperature approx. $10^{\circ}$ higher than a light-coloured gneiss of the same aspect.

The force of katabatic wind is less in the study area than in e.g. Enderby Land and Wilkes Land farther east (Müller 1982; Vinje 1962). Only breeze or moderate gale occurred regularly,
Table 7. Air and surface temperatures on summit $2,188 \mathrm{~m}$ a.s.1. S of Horten, Gjelsvikfjella, 27-29 January 1985.

Mean diurnal air temperature

Mean maximum air temperature

Mean minimum air temperature

$-8$

Surface temperatures 29 January, 1500 hrs., ambient air $-10^{\circ} \mathrm{C}$ :

\begin{tabular}{lcc}
\hline Surface inclination & $2^{\circ} \mathrm{S}$ & $60^{\circ} \mathrm{N}$ \\
\hline Dark biotite/pyroxene rock & +8 & $+18-+23$ \\
Light gneiss & +1 & +12 \\
Snow (horizontal surface) & & -9 \\
\hline
\end{tabular}

especially during nights following sunny days, or in connection with cyclone passages on the coast.

\section{Microthermal measurements}

The air temperature, cloud cover, and average windspeed entered in Table 8 are considered representative of the summer (mid-January) and early autumn (mid-February) seasons at Camp Norway 5, 1,600 m a.s.l. 
Table 8. Air and vegetation temperatures and some other meteorological parameters at the reference site at Camp Norway 5 , Svarthamaren, Mühlig-Hofmannfjella, $1,600 \mathrm{~m}$ a.s.l. Mid-summer and autumn.

\begin{tabular}{|c|c|c|c|c|c|c|}
\hline \multirow{2}{*}{$\begin{array}{l}\text { Season and main } \\
\text { weather situation }\end{array}$} & \multirow{2}{*}{$\begin{array}{l}\text { Mean } \\
\text { temperature } \\
{ }^{\circ} \mathrm{C}\end{array}$} & \multirow[t]{2}{*}{ Air } & \multicolumn{2}{|c|}{ Vegetation category and aspect } & \multirow{2}{*}{$\begin{array}{l}\text { Cloud } \\
\text { cover } \\
\text { Octas }\end{array}$} & \multirow{2}{*}{$\begin{array}{l}\text { Mean } \\
\text { windspeed } \\
\mathrm{m} \mathrm{s}^{-1}\end{array}$} \\
\hline & & & $\begin{array}{l}\text { Epilithic Lecidea } \\
\text { crust, } 60^{\circ} \mathrm{NW}\end{array}$ & $\begin{array}{l}\text { Prasiola, } \\
10^{\circ} \mathrm{NW}\end{array}$ & & \\
\hline Midsummer, 15-16 & Diurnal & -8 & +2.5 & -0.5 & 0 & 5 \\
\hline January. Clear, & Maximum & -4 & +19 & +13 & & \\
\hline sunny days. & Minimum & -12 & -4.5 & -7 & & \\
\hline Early autumn, 9-14 & Diurnal & -13 & -4.5 & -12 & 2 & 2 \\
\hline February. Clear days & Maximum & -11 & +15 & -6 & & \\
\hline $\begin{array}{l}\text { with hazy sun; cold } \\
\text { nights. }\end{array}$ & Minimum & -16 & -15 & -15.5 & & \\
\hline
\end{tabular}

* Anemometer registration at synoptic times.

Superficial ground and vegetation temperatures were measured hourly during the same periods with PT 100 thermistors connected to a Grant paper chart recorder. Operation of the instrument was hampered by severe night cold and drifting snow. Two different kinds of extremely sparse monospecific vegetation were selected as representative for the microthermal regimen at this site.

A crust of a light-coloured Lecidea sp. (Table 8) represents the most extreme epilithic communities. It occupied a shallow depression in a charnockite boulder, freely exposed to the sun. A $1-2 \mathrm{~cm}$ thick snow drift covered it nearly every night, but thawed before noon and provided liquid water to the lichen. The temperature of the crust, and of the rock surface, rose to $15^{\circ}$ or more in the afternoon when it had dried up, but remained below zero on some autumn days when the snow cover remained.

The other community of the foliose green alga, Prasiola cf. crispa, was growing on moist gravel close to the rock with Lecidea. Part of the algal mat was submerged in a meltwater pond which froze every night, but the temperature sensor was placed in a well-drained mat of the alga. It was continuously frozen during the autumn study period (Table 8 ), but thawed regularly by noon in the mid-summer period.

The ambient air temperature stayed below $-2^{\circ}$ in January and below $-10^{\circ}$ in February. Also the vegetation temperatures underwent a change after early February. Mid-day thawing became less regular in the lichen crust, and the frozen periods became longer, so as to terminate the period of growth.

These results are in accordance with measurements in invertebrate habitats at a nearby site during January and February 1985 (Sømme 1985, Fig. 3).

\section{Water supply of the vegetation}

All available water is derived from local snow melting, which usually takes place around noon and ceases in the afternoon. This radiative melting proceeds from the margins of the snowfields or on dirty ice and snow, and is sufficient to form ponds and runnels, e.g. at Camp Norway 5 (Sømme 1985, Fig. 1) and inside the Jutulsessen amphitheatre (Fig. 4). Water enclosed in cavitation hollows undergoes the same diurnal cycle.

There are several open pools of the proglacial type (Heywood 1984, p. 280), and lakelets with connecting brooks in the morainic SW cirque of Jutulsessen (JU 21-22) and in Grjotlia (JU 19).

\section{Assessment of the bioclimate}

The general features of various Antarctic climates are well documented, with the possible exception of nunatak climates, and their geobotanical correlates were summarized by Smith (1984, Table 1). Microthermal studies such as those presented here, and such as those by Kappen (1985b) confirm the importance of radiation for rising the tissue temperature of plants above the freezing point, and providing liquid water in a very arid environment.

The nunataks fringing the Polar plateau are unquestionably the coldest regions on earth available to terrestrial biota. An assessment of the mountain climate in Dronning Maud Land would be premature, but the automatic station placed at $1,350 \mathrm{~m}$ a.s.1. in Jutulsessen (Gjessing 1985) is now recording air and soil temperatures for later retrieval. 
The summer temperatures in the mountains are certainly lower than at coastal stations such as Novolazarevskaya and Syowa (Tables 4, 5, 6). The thermal climate at the $1,600 \mathrm{~m}$ level may be more similar to that of shelf stations at higher latitude, such as General Belgrano and Halley Bay.

The clear sky prevailing in the interior mountains is an important factor to enhance radiative heating of the ground, counteract glacierization, and create local niches for vegetation. The low windspeed also contributes to a bioclimate less inclement than would be expected in Antarctic high mountains close to the Polar plateau. Some parts of the study area, e.g. the interior of Jutulsessen (Fig. 4), enjoy an Antarctic 'oasis' climate, where temporarily open water supports algal vegetation, and ice-free ground harbours cyanophycean, algal, bryophyte and lichen communities. There are also considerable colonies of Antarctic petrels, snow petrels, and skuas.

However, elevations above approx. $2,500 \mathrm{~m}$ a.s.l. seem to have a wind and temperature regimen presumably precluding liquid water which is essential for plants and invertebrates.

\section{Structure and composition of the vegetation}

A provisional classification of plant communities in the study area was proposed by Engelskjøn (1985, p. 47). Some details of their appearance, specific content, and performance, are provided here. A corroborated classification will have to await results of the taxonomical revisions. For some genera, e.g. Buellia, Lecidea, and most algae, referral to species is premature, and provisional names are avoided. The degrees of coverage in some analysed communities are given in the scale of Hult and Sernander (Hult 1881).

The following sub-formations of the Antarctic cold desert cryptogam formation (Aleksandrova 1980) may be identified in the Gjelsvikfjella and Mühlig-Hofmannfjella Mountains:

\section{Unicellular alga sub-formation}

1. Chlamydomonas association. - A dense growth of Chlamydomonas sp. occurred in a pool approximately $1,600 \mathrm{~m}$ a.s.l. below the southern section of the Svarthamaren petrel rookery (see Bech, Haftorn \& Mehlum 1985). The water was yellowish-green, and froze to green ice in midFebruary. Similar algal communities were seen in puddles around a partly frozen, proglacial pool, $1,606 \mathrm{~m}$ a.s.l. (Sømme 1985, Fig. 1), and at sites in Jutulsessen. More intensely guano- and carcasspolluted waterbodies were of a yellowish-brown colour and mainly colonized by bacteria.

No macroscopically visible snow algae vegetation was seen, presumably because the firn contains very little liquid water owing to the low temperatures.

2. Endolithic alga association. - Endolithic, bright green algal growths were often seen in rock fissures and on crystal surfaces of in situ weathered charnockite. Pleurococcus is the most frequent chlorophycean genus in such situations.

\section{Thallose alga sub-formation}

\section{Encrusted cyanophycean-chlorophycean} association.- Various algal assemblages form encrustations or strata on rock surfaces or soil. Greenish-black algal films were seen even at extremely cold- and wind-exposed sites, but there was usually some protection from the abrasion by wind-drifted snow and mineral detritus. The most important constituents are Chroococcus and Pleurococcus. This sociation ascends to the top of the mountain Horten (Fig. 3, RI 3), 2,470 m a.s.l. where it is restricted to cavitation hollows.

Seepage trails ('Tintenstriche') with algal films are typical of smooth gneiss surfaces at lower elevation. A sooty-coloured community of this kind at Plogskaftet (PL 7) contained species of Gloeocapsa and Phormidium.

Wet moraine gravel and runnels support extensive sheets of Nostoc spp. and Oscillatoria/ Phormidium spp. The algae are often encrusted

Table 9. Vegetation analyses of Nostoc communities in the encrusted cyanophycean-chlorophycean association, Gjelsvikfjella. I. Rabben (JU 4), 1,400 m a.s.I. II. Armlenet (JU 6), 1,160 m a.s.l. Coverage in Hult-Sernander's scale.

\begin{tabular}{lcccccc}
\hline & & I & & \multicolumn{3}{c}{ II } \\
Square no. $\left(0.25 \mathrm{~m}^{2}\right)$ & 1 & 2 & 3 & 1 & 2 & 3 \\
\hline Candelariella hallettensis & - & - & - & - & 1 & 1 \\
Lecidea sp. & 1 & - & - & - & - & - \\
Lepraria angardiana & 3 & 2 & 2 & - & - & - \\
Nostoc sp. & 4 & 2 & 2 & 4 & 4 & 5 \\
Boulders, rock surfaces & 4 & 4 & 4 & - & - & - \\
Gravel & 2 & 5 & 5 & 5 & 5 & 4 \\
\hline
\end{tabular}


by the imperfect white lichen, Lepraria angardiana, or by the yellow Candelariella hallettensis. The encrusted Nostoc communities are frequent at lower elevations $(1,100-1,600 \mathrm{~m}$ a.s.l.) and require some protection from wind and a sufficient supply of meltwater (Tables 2, 9).

2. Prasiola-Ulothrix association. - This is structured by larger, thallose chlorophyceans. A nearly monospecific Prasiola sociation was extensive at Svarthamaren (SH 1, cf. Sømme 1985, Fig. 1), and luxuriant stands of the same species up to $5 \mathrm{~cm}$ thick are frequent in the interior of Jutulsessen (JU 20, 22). Prasiola communities show a preference for the periphery of bird colonies, especially the skua habitats, but do not tolerate the excessive manuring in their central parts, which are also too dry. Nor does Prasiola ascend to the highest nunataks, the altitudinal limit being approx. $1700 \mathrm{~m}$ a.s.l.

Cyanophyceans, e.g. Phormidium and Lyngbya, are frequent as accessory components of the chlorophycean communities.

A Phormidium sp. made up large, greyishbrown mats and filaments in bird-polluted puddles and brooks in Jutulsessen (JU 20, 22). A bright green community of Ulothrix sp. and filamentous growth forms of Prasiola occurred in less polluted stream water at Grjotlia (JU 19).

\section{Epilithic lichen sub-formation}

The lichen communities on rock surfaces may be classified according to preferred substratum, altitudinal level, and species content.

\section{Lecania sp. - Lecidea spp. - Umbilicaria decus-} sata association. - This provisional name comprises lichen assemblages occupying exposed cliffs and boulders, often at the higher altitudes. There is only one foliose species, Umbilicaria decussata, and one fruticose species, Pseudephebe minuscula. Most of the crustose species have been determined only to genus. Among these, a Lecidea sp. occurred up to approx. 2,550 $\mathrm{m}$ a.s.l. on the mountain Terningskarvet (RI 5) and to 2,471 ma.s.l. on Horten (RI 3). Three other lichen species were collected above $2,400 \mathrm{~m}$ a.s.l.: Buellia frigida, Pseudephebe minuscula, and Umbilicaria decussata, while a further four occurred above $2,100 \mathrm{~m}$ a.s.1.: Acarospora chlorophana, Candelariella hallettensis, Lecanora expectans, and Rhizoplaca melanophthalma. This high altitude vegetation usually shows a reduced vegetative development, Umbilicaria thalli measuring only $1 \mathrm{~cm}$ across. At still higher elevations, 2,680 m a.s.l. (SH 5) and 2,695 m a.s.l. (CU 5) there was no macrovegetation. Accordingly, the upper altitudinal limit of lichens is approx. $2,500 \mathrm{~m}$ a.s.l. in the study area.

\section{Xanthoria elegans association.-Xanthoria} (Caloplaca) elegans is widely dispersed below $1,880 \mathrm{~m}$ a.s.l. and forms continuous crusts on some dark, fine-crystalline rocks. It is a component of several plant communities, including those slightly influenced by bird manure. The following sociations may be distinguished:

(1) Xanthoria elegans-Candelariella hallettensis-Nostoc sociation occupying plains of biotitepyroxene lithosol at Jutulsessen (JU 1, 11, 12). There are few other species associated (Table 10). The substratum is alkaline with $\mathrm{pH}$ up to 8.7 (Table 2).

(2) Xanthoria elegans-Physcia caesia-Umbilicaria aprina sociation on protected, rocky slopes with some bird influence, e.g. on the lower nunataks of Jutulsessen (JU 1), Hamarskaftet (HA 1, 3, 4) and Plogskaftet (PL 9). The main species are usually well developed - Umbilicaria aprina up to $15 \mathrm{~cm}$ across, and there are many additional species (Table 11).

(3) Xanthoria elegans-Buellia frigidaAcarospora gwynnii sociation on exposed, smooth rock surfaces. Acarospora gnynnii was observed only on the mafic rocks of Jutulsessen (JU 1). Related communities with prominent $X$. elegans were seen in many places, but the species content declined with increasing altitude.

(4) Xanthoria candelaria sociation which also includes $X$. elegans as a cushion growth form, and Prasiola. It is best developed at protected sites

Table 10. Vegetation analyses of the Xanthoria elegans association, Gjelsvikfjella. 1. Xanthoria elegans-Candelariella hallettensis-Nostoc sociation. Jutulsessen (JU 1), 1,300 m a.s.l. Coverage in Hult-Sernander's scale.

\begin{tabular}{lccccc}
\hline Square no. $\left(1 \mathrm{~m}^{2}\right)$ & 1 & 2 & 3 & 4 & 5 \\
\hline Candelariella hallettensis & 1 & 1 & 1 & 1 & 1 \\
Lecanora expectans & - & 1 & - & 1 & - \\
Xanthoria candelaria & - & 1 & - & - & - \\
$X$. elegans & 2 & 1 & 1 & 2 & 1 \\
Nostoc sp. & 2 & 2 & 2 & 1 & 1 \\
Stones and pebbles & 5 & 5 & 5 & 5 & 5 \\
Gravel & 1 & 3 & 3 & 2 & 1 \\
\hline
\end{tabular}


Table 11. Vegetation analyses of the Xanthoria elegans association. 2. Xanthoria elegans-Physcia caesia-Umbilicaria aprina sociation. I. Hamarskaftet (HA 4), 1,580 m a.s.l. II. Jutulsessen (JU 1) 1,370-1,380 m a.s.l. Coverage in Hult-Sernander's scale.

\begin{tabular}{|c|c|c|c|c|c|c|c|c|c|c|c|c|c|}
\hline \multirow[b]{2}{*}{ Square no. $\left(0.25 \mathrm{~m}^{2}\right)$} & \multicolumn{7}{|c|}{ I } & \multicolumn{6}{|c|}{ II } \\
\hline & 1 & 2 & 3 & 4 & 5 & 6 & 7 & 1 & 2 & 3 & 4 & 5 & 6 \\
\hline Acarospora gwynnii & - & - & - & - & - & - & - & - & - & - & 1 & 1 & - \\
\hline Buellia frigida & 1 & - & - & - & - & - & - & 1 & - & - & - & - & 3 \\
\hline Buellia sp. I (grey) & - & 1 & 1 & 1 & - & - & - & - & - & - & - & - & - \\
\hline Buellia sp. II (yellowish) & 2 & - & 1 & - & - & - & 1 & - & - & - & - & - & - \\
\hline Candelariella hallettensis & - & - & 1 & 1 & 1 & 1 & 1 & 1 & 1 & 1 & 1 & 1 & - \\
\hline Lecidea sp. & 1 & - & - & - & 1 & 3 & 2 & - & 1 & - & - & 1 & - \\
\hline Lepraria angardiana & - & - & - & - & - & - & - & - & - & 1 & - & - & - \\
\hline Physcia caesia & 1 & - & 2 & 2 & 1 & 2 & - & - & - & 2 & - & 1 & - \\
\hline Rhizoplaca melanophthalma & - & - & 1 & - & - & - & - & - & - & - & - & - & - \\
\hline Umbilicaria aprina & 2 & - & 2 & 1 & 1 & - & - & 2 & - & 2 & 一 & 2 & 3 \\
\hline U. decussata & - & - & - & 1 & - & - & - & - & - & - & 2 & - & - \\
\hline Xanthoria elegans & 4 & 3 & 4 & 4 & 3 & 2 & 3 & 2 & 1 & 3 & 1 & 3 & 1 \\
\hline Nostoc sp. & - & - & 1 & - & - & 3 & 2 & - & - & - & - & - & - \\
\hline Oscillatoria/Phormidium sp. & - & - & 1 & - & - & 1 & 1 & - & - & - & - & - & - \\
\hline Boulders, rock surfaces & 4 & 5 & 4 & 3 & 5 & 5 & 5 & 5 & 5 & 5 & 5 & 5 & 5 \\
\hline Gravel & - & - & - & 3 & 1 & 2 & 1 & - & - & - & - & - & - \\
\hline
\end{tabular}

such as abandoned snow petrel nests on the lower nunataks.

3. Rhizocarpon geographicum association. - Rhizocarpon geographicum and Lecanora sverdrupiana occupy protected rock crevices with intermittent seepage, growing in narrow strips up to $3 \mathrm{~m}$ long. Habitats supporting one or both of these species, and few others, apart from cyanophyceans, were encountered on the lower gneiss or charnockite nunataks of Stabben (JU 3), Rabben (JU 4), Skigarden (SK 2), Plogskaftet (PL 2, 9), and Cumulusfjellet (CU 1, 3, 4). Stands are of limited extent but may be placed in a separate association because of special demands of hydrology and exposure, and avoidance of bird influence.

\section{Fruticose lichen sub-formation}

This comprises communities of larger lichens in rock gaps, amongst boulders, or in cavitation hollows facing north.

1. Usnea sphacelata-Pseudephebe minuscula association. - This occupies rocky surfaces which are not subject to exfoliation or excessive wind abrasion. Other important species are Umbilicaria aprina and/or $U$. decussata and, in the understorey, Candelariella hallettensis and Xanthoria elegans. Transitional facies to the Xanthoria elegans association are frequent.
The most prominent species, Usnea sphacelata, was never seen above $1,900 \mathrm{~m}$ a.s.l. It becomes rare towards the interior part of the Gjelsvikfjella and Mühlig-Hofmannfjella Mountains and is markedly affected by snow abrasion on exposed cliffs, the branches becoming razed to the same level as the adjacent higher features of the microrelief.

2. Usnea sphacelata-Grimmia lawiana association. - In addition to the bushy Usnea, this association has a humic understorey of the moss Grimmia lawiana which grows between the stones with attached fruticose lichens (Table 12.1). It requires more wind protection and snow accumulation than the preceding association. Lepraria angardiana and various cyanophyceans commonly encrust the Grimmia cushions.

\section{Moss cushion sub-formation}

Habitats with predominant moss cushions are confined to the most favourable sites within the study area. They show a considerable biological diversity, including several invertebrate groups (Sømme pers. comm.).

1. Grimmia lawiana association. - The most widespread moss species in these mountains is Grimmia lawiana which forms small stands on moist charnockite and gneiss gravel (Table 2). The cushions are up to $15 \mathrm{~cm}$ across and may be confluent. 
Table 12. Vegetation analyses of the moss cushion sub-formation. Jutulsessen (JU 1), 1,370 m a.s.l. Coverage in Hult-Sernander's scale.

\begin{tabular}{lllll}
\hline Square no. $\left(0.25 \mathrm{~m}^{2}\right)$ & 1 & 2 & 3 & 4 \\
\hline $\begin{array}{l}\text { Grimmia lawiana } \\
\text { Sarconeurum glaciale }\end{array}$ & 2 & - & - & - \\
Acarospora gwynnii & 1 & - & 1 & - \\
$\begin{array}{l}\text { Buellia sp. } \\
\text { Candelariella hallettensis }\end{array}$ & 1 & - & 1 & - \\
Lecidea sp. & 1 & 2 & 1 & 1 \\
Lepraria angardiana & 2 & 1 & 1 & 2 \\
$\begin{array}{l}\text { Physcia caesia } \\
\text { Rhizoplaca }\end{array}$ & - & 1 & - & - \\
melanophthalma & - & 1 & 1 & - \\
Umbilicaria aprina & & & & \\
Usnea sphacelata & - & 2 & - & - \\
Xanthoria elegans & 3 & - & 1 & - \\
Boulders, rock surfaces & 1 & 2 & 1 & 1 \\
Gravel, silt & 4 & 5 & 5 & 5 \\
\hline
\end{tabular}

Their central parts are always necrotic, and encrusted by Lepraria angardiana or by a characteristic, brown Stigonema sp. as well as Chroococcus, Scytonema, Stichococcus, and Synechococcus.

Transitions are frequent to the Usnea sphacelata-Grimmia lawiana association (Table 12.1), but Usnea is often absent from the moss habitats.

The vertical range of the Grimmia association is from 1,300 to $1,800 \mathrm{~m}$ a.s.l. Well-developed stands were seen at Rabben (JU 4), Skigarden (SK 2, 3), Hamarskaftet (HA 3), Plogskaftet (PL $1,2,4,7,9$ ), Cumulusfjellet (CU 2), and Ahlstadhottane (AH 2, 3).

2. Sarconeurum glaciale association. - S. glaciale is confined to lithosol and detritus with an alkaline $\mathrm{pH}$ reaction (Table 2). However, Grimmia and Sarconeurum grow together at a few localities, especially in Jutulsessen.

Communities containing Sarconeurum cushions were encountered from 1,100 to $1,500 \mathrm{~m}$ a.s.l. in Jutulsessen (JU 1, 21, 22, 23). The necrotic central parts are commonly encrusted by Candelariella hallettensis, Lecidea sp., and Lepraria angardiana, cf. Table 12.2-4.

\section{Discussion}

\section{Physical limitations upon vegetation}

The area under consideration is an Antarctic mountain desert with restricted enclaves of an oligospecific, but ecologically differentiated, nonvascular vegetation. The oasis area of Jutulsessen is of the wet type (Walton 1984, p. 16), as contrasted with Antarctic dry valleys (Cameron 1972).

The bioclimate is dependent on heat gain from solar radiation, which compensates for the low ambient air temperatures during the growing season. This thermal radiation increment (Wilson 1963 , p. 23) creates microenvironments which are more favourable to plant growth than would be expected at high altitudes. It also lessens the effect of wind chill and cooling power. During the Antarctic summer, the latter is comparable to the coldest months in North Scandinavia (Vinje 1965, p. 194), and it may be increased by snow carried in the airstream. Conversely, the lower air density at high elevations leads to a decrease of convective heat loss by 16-20\% (Vinje 1962). Hence the importance of the vertical temperature decrease may be less than in maritime Antarctic areas (see Engelskjøn 1986).

Even mosses, which are the highest form of plant life in continental Antarctica, may reach considerable altitudes. However, there are latitudinal and altitudinal limits to macroscopic plant life.

Communities of a few lichens and the most hardy algae ascend to approximately $2,500 \mathrm{~m}$ a.s.l. in the Gjelsvikfjella Mountains. This is the highest station known for plant life in Antarctica, at least as regards published records (see Wise \& Gressitt 1965; Cameron et al. 1971). Above this elevation, the combined effect of wind, severe cold, radiation, and drought result in a climate that excludes most plants, with the possible exception of endolithic algae and lichens (Kappen \& Friedmann 1983).

The radiation, humidity, wind, and thermal regimen on Antarctic nunataks require an integrated micrometeorological assessment. For this purpose, Gjessing (1985) has established data logging instruments at Jutulsessen ( $\mathrm{JU} \mathrm{1}$ ) and Svarthamaren (SH 1). However, it is possible to interpret cryptogam distribution assuming a simple relationship between heat sums during summer, expressed as Degree-Days for December-January (DD-2, Tables 5, 6), and the performance of vegetation, omitting consideration of thermal radiation increment and the convective cooling.

The coastal oases, e.g. Novolazarevskaya and Syowa, enjoy a relatively favourable climate, DD- 
2 being higher than -100 . The ice shelf stations have heat sums -300 or lower, and a similar figure has been estimated for the interior mountains.

Mosses (Grimmia lawiana) were found up to $1,800 \mathrm{~m}$ a.s.l., corresponding to a DD-2 of approximately -600 . Elsewhere in the Antarctic, mosses have been recorded southwards to $84^{\circ} 35^{\prime}$ in the Transantarctic Mountains, midway between the McMurdo station and the South Pole, at altitudes from 457 to $762 \mathrm{~m}$ a.s.l. (Wise \& Gressitt 1965). A simple calculation based on these stations gives a DD-2 of -680 as the upper thermal limit for mosses in this part of Antarctica.

The Gjelsvikfjella upper limit of lichens corresponds to a DD- 2 lower than -800 , possibly about $-1,000$. Lichens are known southwards to $86^{\circ} 09^{\prime}$ in the Horlick Mountains, at an altitude of 1,980 $\mathrm{m}$ a.s.l. (Wise \& Gressitt 1965; Cameron et al. 1971), only some $430 \mathrm{~km}$ from the South Pole and at $820 \mathrm{~m}$ lower elevation. A calculation as above suggests that the lichens in question may tolerate a DD-2 lower than -1000 , which implies that lichens may grow up to approximately $2,000 \mathrm{~m}$ a.s.l. everywhere in continental Antarctica, provided a suitable microniche exists.

The soils of the study area are all of the frigic type with a negligible amount of humus. They show a considerable range of $\mathrm{pH}$ and metallic cation content (Table 2). Bird influence varies from excessive to virtually none (Table 3 ).

Some areas of exposed soil or stone pavements are devoid of vegetation, e.g. Skigarden (SK 3, Fig. 7), summit 1,390 in Jutulsessen (JU 19), and north of Stabben (JU 2, Fig. 9). Excepting disturbance from glacial activity and possible toxic influence, a main cause of barrenness is mechanical wear and instability. This is particularly so for the coarse charnockite which is exfoliated and fragmented into a barren detritus of feldspar crystals. The rugged surfaces resulting from the honeycomb weathering (Fig. 8) are also unsuitable for lichen attachment. Lindsay \& Brook (1971) noted that dolerite is the principal substratum for lichens in the Theron Mountains, immediately west of Dronning Maud Land. Also within the study area, the richest lichen communities were found on dark, fine-crystalline rocks.

A further cause of barrenness is the lack of meltwater. Wind-drifted snow thawing around midday is the main source of liquid water, and the snow deposition is intimately related to wind direction and local topography.

\section{Regional comparisons of vegetation}

Descriptions of vegetation from adjoining coastal areas and mountains (Figs. 1,10) are sparse. With due regard for complicated synonymy; published records of lichen and moss species may give an idea of their relative frequency.

In the areas to the west, Lindsay (1971) recorded 13 lichen species from Tottanfjella. At least nine of them were collected in the present study area. The lichen flora of Vestfjella is well documented (Lindsay 1972; Øvstedal 1983b), and of about 20 species recorded, almost all were collected in Gjelsvikfjella and MühligHofmannfjella. Bryophyte collections by the Camp Norway 6 party (Engelskjøn 1985; Blom unpublished) suggest a locally rich moss vegetation in Vestfjella, the highest elevation of which is only $1,132 \mathrm{~m}$ a.s.l. There appear to be close floristic and vegetational connections between $\mathrm{H}$. U. Sverdrupfjella, Gjelsvikfjella and Mühlig-Hofmannfjella, judging from the collections examined by $\emptyset$ vstedal (1983a).

In the areas to the east, Dodge (1962) records 10 lichen species from the Sør-Rondane Mountains. Although a complicated state of synonymy does exist (cf. Lindsay 1972, pp. 18-19), it is likely that eight species are identical with ecologically important species in the present study area. Little is known of the development of vegetation of SørRondane. The mountains are physiographically very similar to Mühlig-Hofmannfjella (van Autenboer 1964) and up to $3,180 \mathrm{~m}$ high. Most collections (Dodge op. cit.) were made at $1,500 \mathrm{~m}$ a.s.l.

Reports of botanical observations in the Dronning Fabiolafjella (Yamato) Mountains have not been traced.

Among 17 lichen species identified from the Syowa station area and adjacent mainland (Kashiwadani 1970), at least 15 were found in the mountains of Gjelsvikfjella and Mühlig-Hofmannfjella, approx. $1,300 \mathrm{~km}$ to the west. There are few lichens on the Onguløyene Islands, presumably because of their gravelly substratum (Matsuda 1968, Figs. 5-9). Further vegetational studies were made by Kobayashi (1974) and Nakanishi (1977). The principal lichens in the plant communities are generally the same as in the present study area, but the mosses are of other genera: Bryum spp. and Ceratodon purpureus (Horikawa \& Ando 1967; Matsuda 1968; Ando 1979). This suggests that the coastal areas at the Syowa station 
enjoy a zonal climate more favourable to vegetation than in the interior mountains (see also the present Tables 4, 5 and Matsuda 1968, pp. 23).

Farther east in Greater Antarctica (Enderby Land, MacRobertson Land, Wilkes Land) comprehensive information for vegetational comparison has been provided i.a. by Savich-Ljubitskaya \& Smirnova (1961), Kuc (1969), Filson (1974, 1975, 1982), Pickard (1982), Seppelt (1984), Seppelt \& Ashton (1978); and the recent contributions of Kappen (1985a, b) from the coast of northern Victoria Land reveal vegetational similarities to Dronning Maud Land, which is in a diametrically opposite position in Antarctica.

To illustrate the problems caused by taxonomic ambiguity, I refer to Kappen (1985a, p. 223) who states that Acarospora chlorophana (Wg.) Mass. is absent from his study area. However, he records Biatorella antarctica Murray with $B$. cerebriformis (Dodge) Filson as a synonym. Actually these taxa are conspecific with $A$. chlorophana, according to $\emptyset$ vstedal (1983b, p. 218).

\section{Chorological aspects of vegetation}

From the review in the preceding section it may be concluded that the terrestrial flora and vegetation show close relations in the part of Greater Antarctica extending from the Vestfjella Mountains to northern Victoria Land. This fact is also evidenced by the maps of plant distribution by Greene et al. (1967), although these include very few records from Dronning Maud Land due to its incomplete exploration before 1968/69 (see Lindsay 1972).

This region extends around half of the circumAntarctic area, which includes coastal ice-free areas, sheer shelf ice for thousands of kilometers, some oases inside the shelf ice, and interior mountains with a broken relief and high elevations. A zonality of vegetation is indicated. For instance, the moss cushion sub-formation seems best developed in the coastal zone.

The altitudinal belts in the mountains show a progressive impoverishment of vegetative development and content of species. These zones and vertical belts may be related to the climatic regimen, but premises are still scant for discussing details of zonality.

Concerning agents of dispersal of the flora, wind-drift of diaspores in the air and on the glacier surfaces seems to be important. Within the study area of Gjelsvikfjella and Mühlig-Hofmannfjella, the same species occurred regularly on widely spaced nunataks. Also very small rocks (JU 15 , SK 1, PL 3, 5, erratics at SH 2) contained small lichen thalli, especially Buellia frigida, Candelariella hallettensis, Lecidea sp., Rhizoplaca melanophthalma, Umbilicaria decussata, and Xanthoria elegans.

The wind on the coastal slope blows so steadily from the E or NE that one can set one's course by it (see map in Mather \& Miller 1967). Windborne mineral fragments weighing up to $1.5 \mathrm{~g}$ were dispersed on the ice around rock exposures. This indicates the potential of the airstream to carry plant fragments and spores. Prasiola thalli were seen on the firnfields at Camp Norway 5 (SH 1), and a dry cushion of Sarconeurum glaciale was found displaced on a rock ledge $1,500 \mathrm{~m}$ a.s.l. in the southern cirque of Jutulsessen (JU 12).

Komárek \& Rủžička (1966, p. 239) consider the birds as important for distributing algae from the coast to inland habitats.

Numerous observations in the coastal areas of Greater Antarctica attest to the fact that they were overridden by an enlarged ice sheet during previous glacial maxima (Hollin 1970, p. 17). However, 'the distribution of erratics suggests that during the expansion some of the higher nunataks were always ice free' (Hollin loc. cit.), and it is also suggested that 'perhaps the lowering of sea-level exposed new oases'.

The mountain areas of Mühlig-Hofmannfjella and farther east have been investigated with regard to geomorphology (Bardin et al. 1961) and moraine stages (Bardin \& Sudakova 1972). Of particular significance are the studies in the Amery Oasis (Bardin 1982). Moraines of great thickness were found, and their ages inferred as Miocene/Pliocene, early Pliocene, and late Pliocene. These findings may have regional implications for the possibility of in situ survival of the Antarctic cold desert cryptogam formation throughout the Pleistocene.

Acknowledgements. - I wish to thank all my companions during the Norwegian Antarctic Research Expedition 1984/85, especially the members of the Camp Norway 5 and 6 parties, who contributed plant collections from various areas. Yngvar Gjessing, University of Bergen, also gave advice concerning temperature measurement and instrumentation, and Lauritz Sømme, University of Oslo, provided me with general meteorological observations from Camp Norway 5. 
Randi Skulberg and Olav Skulberg at the Norwegian Institute for Water Research, in charge of isolation and cultivation of cyanophyceans and chlorophyceans, provided some generic determinations of representative samples.

Herbjørn Lysnes, Kjemisk Analyselaboratorium, Statens forskningsstasjon, Holt, performed the soil chemical analyses. At the graphic office of the University of Oslo, René Jacquet prepared the original drawing to Fig. 1, and Per Aas the photographs.

Special thanks are due to the Norwegian Polar Research Institute for giving me the opportunity to join the NARE 1984/ 85 , and to the Botanical Garden and Museum, University of Oslo, for offering working facilities.

The Norwegian Research Council for Science and the Humanities supported part of the present study by grant D. 70.49.085, for which I am indebted.

\section{References}

Akiyama, M. 1967: On some Antarctic terrestrial and subterranean algae. Mem. Fac. Educ. Shimane University 1, 3656.

Aleksandrova, V. D. 1980: The Arctic and the Antarctic: their division into geobotanical areas (translated by D. Löve). Cambridge University Press. 237 pp.

Ando, H. 1979: Ecology of terrestrial plants in the Antarctic with particular reference to bryophytes. Pp. 81-103 in Matsuda, T. \& Hoshai, T. (eds.): Proceedings of the Symposium on Terrestrial Ecosystem in the Syowa Station area. Memoirs of National Institute of Polar Research, Special Issue No. 11.

Ardus, D. A. 1964: Some observations at the Tottanfjella, Dronning Maud Land. British Antarctic Survey Bulletin 3, 17-20.

van Autenboer, T, 1964: The geomorphology and glacial geology of Sør-Rondane, Dronning Maud Land. Pp. 81-103 in Adic, R. J. (ed.): Antarctic geology. North-Holland Publishing Company, Amsterdam.

Bardin, V. I. 1982: Composition of East Antarctic moraines and some problems of Cenozoic history. Pp. 1069-1076 in Craddock, C. (ed.): Antarctic Geoscience. The University of Wisconsin Press.

Bardin, V. I., Dundo, O. P. \& Konovalov, G. V. 1961: Kratkaya geomorfologicheskaya kharakteristika gor Semli Korolevy Maud (Short geomorphological characteristics of the mountains of Dronning Maud Land). Inform. Bull. Soviet Antarct. Exped. 30, 9-12.

Bardin, V. I. \& Sudakova, N. G. 1972: Litologicheskie ozbenosti raznovozrastnykh moren v gorakh Semli Korolevy $\overrightarrow{M a u d}$ (Lithological peculiarities of different age moraines in mountains of Dronning Maud Land). Inform. Bull. Soviet Antarct. Exped. 83, 25-29.

Bech, C., Haftorn, S. \& Mehlum, F. 1985: Ornithological investigations in Mühlig-Hofmannfjella, Dronning Maud Land. Rep. NARE 1984/85. Norsk Polarinstitutt Rapport 22, 27-34.

Blüthgen, J. \& Weischet, W. 1980: Allgemeine Klimageographie. W. de Gryuter, Berlin. 887 pp.

Bowra, G. T. . Holdgate, M. W. \& Tilbrook, P. J. 1966: Biological observations in Tottanfjella and Central Heimefrontfjella. British Antarctic Survey Bulletin 9, 63-70.
Cameron, R. 1972: Microbial and ecologic investigations in Victoria Valley, Southern Victoria Land, Antarctica. Pp. 195-260 in Antarctic Terrestrial Biology. Antarctic Research Series 20. American Geophysical Union. Washington.

Cameron, R., Lacy, G. H., Morelli, F. A. \& Marsh, J. B. 1971: Farthest south soil microbial and ecological investigations. Antarctic Journal of the United States 6, 105-106.

Claridge, G. G. C. \& Campbell, I. B. 1977: The salts in Antarctic soils, their distribution and relationships to soil processes. Soil Science 123, 337-384.

Dodge, C. W. 1962: Expédition Antarctique Belge lichens. Bull. Jard. Bot. Bruxelles 32 (3), 301-308.

Engelskjøn, T. 1985: Botany of Gjelsvikfjella and MühligHofmannfjella, Dronning Maud Land - with some contributions from H. U. Sverdrupfjella and Vestfjella. Rep. NARE 1984/85. Norsk Polarinstitutt Rapport 22, 43-54.

Engelskjøn, T. 1986 (in press): Botany of Bouvetøya, South Atlantic Ocean. II. The terrestrial vegetation of Bouvetøya. Polar Research.

Filson, R. B. 1974: Studies in Antarctic lichens II. Lichens from the Windmill Islands, Wilkes Land. Muelleria 3(1), 9-36.

Filson, R. B. 1975: Studies in Antarctic lichens V: Lichenes Antarctici Exsiccati, Fascicle I, with additional notes on the taxonomy of each species. Muelleria 3 (2), 146-158.

Filson, R. B. 1982: Lichens of continental Antarctica. J. Hattori Botanical Lab. 53, 357-360.

Gjessing, Y. T. 1985: Meteorological and glaciological studies in Dronning Maud Land. Rep. NARE 1984/85. Norsk Polarinstitutt Rapport 22, 63-66.

Golubkova, N. S. 1969: Lichens. Pp. 488-492 in Atlas Antarktiki 2. Hydrometeorological Publishing House, Leningrad.

Greene, S. W., Gressitt, J. L., Koob, D., Llano, G. A., Rudolph, E. D., Singer, R., Steere, V. C. \& Ugolini, F. C. 1967: Terrestrial life of Antarctica. In Bushnell, V. C. (ed.): Antarctic Map Folio Series, Folio 5. American Geographical Society, N.Y.

Heywood, R. B. 1984: Antarctic inland waters. Pp. 279-344 in Laws, R. M. (ed.): Antarctic Ecology I. Academic Press, London.

Hollin, J. T. 1970: Antarctic glaciology, glacial history and ecology. Pp. 15-19 in Holdgate, M. W. (ed.): Antarctic ecology 1. Academic Press, London.

Horikawa, Y. \& Ando, H. 1967: The mosses of the Ongul Islands and adjoining coastal areas of the Antarctic continent. Japanese Antarctic Research Expedition. Sci. Rep. Special Issues 1, 245-252.

Hult, R. 1881: Försök till analytisk behandling af växtformationerna. Medd. Soc. Fauna Fl. Fennica 8.55 pp.

Juckes, L. M. 1969: Weathering hollows in charnockite at Mannefallknausane, Dronning Maud Land. British Antarctic Survey Bull. 22, 97-98.

Kappen, L. 1985a: Vegetation and ecology of ice-free areas of northern Victoria Land, Antarctica. 1. The lichen vegetation of Birthday Ridge and an inland mountain. Polar Biology 4, 213-225.

Kappen, L. 1985b: Vegetation and ecology of ice-free areas of northern Victoria Land, Antarctica. 2. Ecological conditions in typical microhabitats of lichens at Birthday Ridge. Polar Biology 4, 227-236.

Kappen, L. \& Friedmann, E. I. 1983: Kryptoendolithische Flechten als Beispiel einer Anpassung an extrem trockenkalte Klimabedingungen. Verh. Ges. Ökologie 10, 517-519.

Kashiwadani, H. 1970: Lichens of the Prince Olav Coast, Antarctica. Japanese Antarctic Research Expedition. Sci. Rep. Ser. E (30). 21 pp., 3 pl. 
Kobayashi, K. 1974: A preliminary report on the vegetation of the Prince Olav Coast, Antarctica. Antarctic Rec. 51, 18-28.

Komárek, J. \& Ružička, J. 1966: Freshwater algae from a lake in proximity of the Novolazarevskaya Station, Antarctica. Preslia 38, 237-244.

Konovalov, G. V. 1964: Observations of birds in Queen Maud Land. Inf. Bull. Soviet Antarctic Exp. 4, 156-158.

Konovalov, G. V. \& Shulyatin, O. G. 1964: Unikahniji ptitsjui bazar v Antarktide (Unique bird colony in Antarctica). Priroda 10, 100-101.

Kuc, M. 1969: Some mosses from an antarctic oasis. Rév. Bryol. Lichenol. 36 (3-4), 655-672.

Köppen, W. \& Geiger, R. 1936: Handbuch der Klimatologie. Ic. Das geographische System der Klimate. Berlin. 44 pp.

Lindsay, D. C. 1971: Notes on Antarctic lichens. IV. Lichens from Tottanfjella, Dronning Maud Land. British Antarctic Survey Bull. 25, 99-100.

Lindsay, D. C. 1972: Lichens from Vestfjella, Dronning Maud Land. Norsk Polarinstitutt Meddelelser 101. 21 pp.

Lindsay, D. C. \& Brook, D. 1971: Lichens from the Theron Mountains. British Antarctic Survey Bull. 25, 95-98.

MacNamara, E. E. 1969: Biological research opportunities at the Soviet Antarctic Station Molodezhnaya. Antarctic Journal of the United States 4 (3), 8-12.

MacNamara, E. E. 1973: Macro- and microclimate of the Antarctic coastal oasis Molodezhnaya. Biuletyn Peryglacjalnyj 23, 201-236.

Mather, K. B. \& Miller, G. S. 1967: Notes on topographic factors affecting the surface wind in Antarctica; with special reference to katabatic winds. University of Alaska UAG-R189. 125 pp. (map reproduced in Walton 1984, Fig. 7).

Matsuda, T. 1978: Ecological study of the moss community and microorganisms in the vicinity of Syowa Station, Antarctica. Japanese Antarctic Research Expedition Sci. Rep. Ser. E (29). $58 \mathrm{pp}$.

Matsuda, T. \& Hoshai, T. (eds.) 1979: Proceedings of the Symposium on Terrestrial Ecosystem in the Syowa Station area. Memoirs of National Institute of Polar Research, Special Issue No. 11.

Müller, M. J. 1982: Selected climatic data for a global set of standard stations for vegetation science. W. Junk, Haag. 306 pp.

Nakanishi, S. 1977: Ecological studies of the moss and lichen communities in the ice-free areas near Syowa Station, Antarctica. Antarctic Rec. 59, 69-96.

Ohta, Y. \& Tørudbakken, B. 1985: Geology of Gjelsvikfjella and western Mühlig-Hofmannfjella, Dronning Maud Land. Rep. NARE 1984/85. Norsk Polarinstitutt Rapport 22, 35-41.

Orheim, O. 1985: General report of the expedition. Rep. NARE 1984/85. Norsk Polarinstitutt Rapport 22, 7-18.

Pickard, J. 1982: Vegetation of the Vestfold Hills, Antarctica: A progress report. J. Hattori Botanical Lab. 52, 295-297.

Ravich, M. G. \& Soloviev, D. S. 1966: Geologija i petrologija tsentralnoi chasti gor Semli Korolevy Maud (Geology and petrology of the mountains of central Dronning Maud Land). Ministry of Geology of the USSR. 141.290 pp. (Translated in Jerusalem, 1969.)

Roer, N. 1954: Landmålerliv i Dronning Maud Land. Norsk Tidsskrift for Jordskifte og Landmáling 3, 246-265. Also Norsk Polarinstitutt Meddelelser 78.

Savich-Ljubitskaya, L. I. \& Smimova, Z. N. 1961: On the modes of reproduction of Sarconeurum glaciale (Hook. f. \&
Wils.) Card. \& Bryhn, an endemic moss of the Antarctic. Rév. Bryol. Lichénol. 30, 216-222.

Savich-Ljubitskaya, L. I. \& Smirnova, Z. N. 1969: Mkhi vostochnoy Antarktidy (Mosses of the eastern Antarctic). Pp. 484-492 in Atlas Antarktiki 2. Hydrometeorological Publishing House, Leningrad.

Seppelt, R. D. 1984: The bryoflora of the Vestfold Hills and Ingrid Christensen Coast, Antarctica. Australian National Antarctic Research Expedition Res. Notes 20. $31 \mathrm{pp}$.

Seppelt, R. D. \& Ashton, D. H. 1978: Studies on the ecology of the vegetation at Mawson Station, Antarctica. Australian J. Ecol. 3, 373-388.

Shimizu, H. 1977: Vegetational distribution and habitats on West Ongul and Teøya Islands, Antarctica. Antarctic Record 59, 97-107.

Siple, P. A. 1938: The Second Byrd Antarctic Expedition Botany. I. Ecology and geographical distribution. Annals of the Missouri Botanical Garden 25 (2), 467-514.

Siple, P. A. \& Passel, C. F. 1945: Measurement of dry atmospheric cooling in sub-freezing temperatures. U.S. Antarctic Service Expedition 1939-1941. Proceedings of the American Philosophical Society 89, 177-199.

Smith, R. I. L. 1984: Terrestrial plant biology of the subAntarctic and Antarctic. Pp. 61-162 in Laws, R. M. (ed.): Antarctic Ecology I. Academic Press, London.

Sømme, L. 1985: Terrestrial invertebrates of Mühlig-Hofmannfjella. Rep. NARE 1984/85. Norsk Polarinstitut Rapport 22, 55-65.

Ugolini, F. C. 1972: Ornithogenic soils of Antarctica. Pp. 181193 in Antarctic Terrestrial Biology. Antarctic Research Series 20. American Geophysical Union, Washington.

Ugolini, F. C. 1977: The protoranker soils and the evolution of an ecosystem at Kar Plateau, Antarctica. Pp. 1091-1110 in Llano, G. A. (ed.): Adaptations within Antarctic Ecosystems. Gulf Publishing Company, Houston, Texas.

Ugolini, F. C. \& Starkey, R. L. 1966: Soils and microorganisms from Mount Erebus, Antarctica. Nature (London) 211, 440441.

Vinje, T. E. 1962: The cooling power in Antarctica. Norsk Polarinstitutt Árbok 1961, 7-22.

Vinje, T, E. 1965: On the cooling power in Norway. Norsk Polarinstitutt Arbok 1963, 193-196.

Walton, D. W. H. 1984: The terrestrial environment. Pp. 1-60 in Laws, R. M. (ed.): Antarctic Ecology I. Academic Press, London.

Wilson, O. 1963: Cooling effect of an Antarctic climate on man. Norsk Polarinstitut Skrifter 128. 32 pp.

Wise, K. A. J. \& Gressitt, J. L. 1965: Far southern animals and plants. Nature (London) 207, 101-102.

Worsfold, R. J. 1967: Physiography and glacial geomorphology of Heimefrontfjella, Dronning Maud Land. British Antarctic Survey Bull. 11, 49-57.

Yamanaka, M. \& Sato, K. 1977: Distribution of terrestrial plant communities near Syowa Station in Antarctica, with special reference to water supply and soil property. Antarctic Rec. 59, 54-67.

Øvstedal, D. O. 1983a: Some lichens from H. U. Sverdrup Mountains, Dronning Maud Land, Antarctica. Nova Hedwigia 27, 683-690.

Øvstedal, D. O. 1983b: Some lichens from Vestfjella, Dronning Maud Land Antarctica. Cryptogamie, Bryologie, Lichénologie 4, 217-226. 